\author{
ARGONNE NATIONAL LABORATORY \\ P. O. Box 299 \\ Lemont, Illinois
}

CASTING URANIUM -5 w/o ZIRCONIUM $-1.5 \mathrm{w} / 0$ NIOBIUM ALLOYS INTO ZIRCONIUM AND ZIRCALOY-2 CONTAINERS

by

J. W. Frank and R. E. Macherey

Metallurgy Division

Program 1.1 .24

Published July, 1958

Portions of the material in this report have appeared in the following Metallurgy Division Quarterly Reports:
ANL-4581
pp. 25
December 31, 1950
ANL-5257
pp. $10-11$
March 31, 1954
ANL-5338
pp. $10-20$
June 30,1954
ANL-5382 pp. 9-15
September 30, 1954
ANL-5423
pp. $11-17$
December 31, 1954

Operated by The University of Chicago

under

Contract W-31-109-eng-38 


\section{DISCLAIMER}

This report was prepared as an account of work sponsored by an agency of the United States Government. Neither the United States Government nor any agency Thereof, nor any of their employees, makes any warranty, express or implied, or assumes any legal liability or responsibility for the accuracy, completeness, or usefulness of any information, apparatus, product, or process disclosed, or represents that its use would not infringe privately owned rights. Reference herein to any specific commercial product, process, or service by trade name, trademark, manufacturer, or otherwise does not necessarily constitute or imply its endorsement, recommendation, or favoring by the United States Government or any agency thereof. The views and opinions of authors expressed herein do not necessarily state or reflect those of the United States Government or any agency thereof. 


\section{DISCLAIMER}

Portions of this document may be illegible in electronic image products. Images are produced from the best available original document. 
$\underline{\text { Page }}$

ABSTRACT ....................... 7

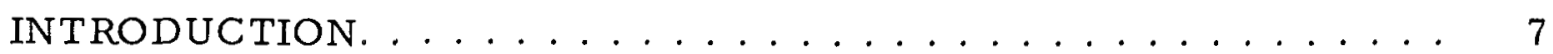

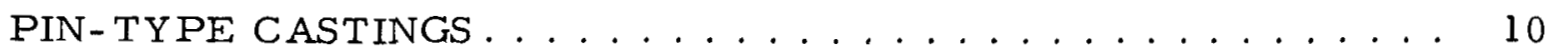

CASTINGS OF INTERMEDIATE DIAMETER . . . . . . . . Il

CASTINGS OF LARGE DIAMETER . . . . . . . . . . 14

RECTANGULAR CROSS-SECTIONAL CASTINGS . . . . . . . 16

SIDE STRIP AND BATHTUB CASTINGS . . . . . . . . . 19

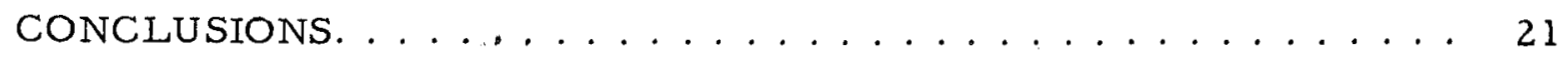

ACKNOWLEDGEMENTS . . . . . . . . . . . . . . . 22

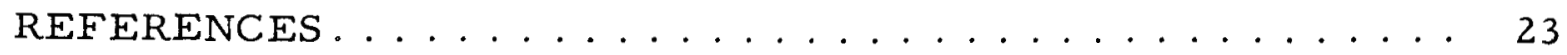




\section{LIST OF TABLES}

No.

Title

I. Casting Data for Small Cylindrical Cans

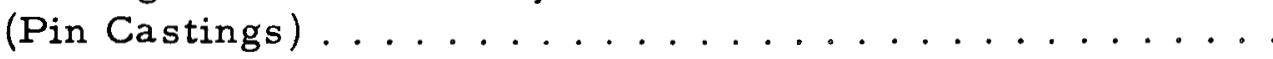

II. Analyses of Uranium Alloy in Pin Castings . . . . . . . . . 25

III. Casting Data for $1 \frac{1}{4} "$ O.D. $x 1 "$ I.D. Cans .......... 25

IV. Casting Data for Large Diameter Cans ........... 26

V. Casting Data for Square-Cornered Rectangular Cans . . . . 26

VI. Casting Data for Round-Cornered Rectangular Cans . . . . . 27

VII. Analyses of Zircaloy-2 Cans Embrittled during Melt Cycle ........................ 28

VIII. Casting Data for Side Strip Castings ............. 28 
LIST OF FIGURES

No.

Title

Page

1. Sketch of Crucible, Heater, Can, and Can Fixture

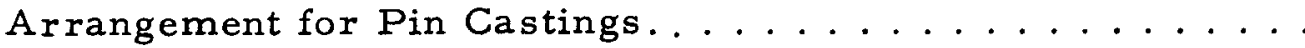

2. Graphite Fixture for Support and Heating Zircaloy-2

Cans for Pin Castings ..................

3. Photographs of Pin Castings with Top $1 / 2 "$ Removed

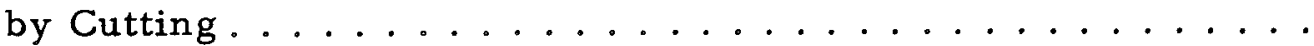

4. Photomicrograph of Zircaloy-2 Uranium Core Interface

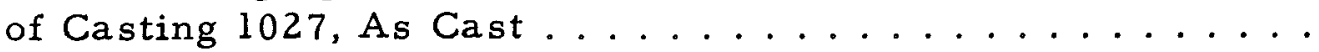

5. Graphite Fixture for Support and Heating of Zircaloy-2 Cans for $1 \frac{1}{4} n$ Diameter Castings ..............

6. Top View and Four Transverse Sections of Casting 1001 Showing Unbond in Can Weld Areas and Internal Porosity ...

7. Casting 1007 Sectioned Just below Core Level.........

8. Zircaloy-2 Uranium Alloy Diffusion Bond of Casting 1005 As Cast and Rolled and Heat Treated ............

9. Unbond between Uranium Core and Zirconium Side Plate in a Rolled Fuel Plate ...................

10. Casting 1044 Sectioned to Show Concentration of Blowholes at Core-Clad Interface .............

11. Equilibrium Pressure of $\mathrm{H}_{2}$ over $\mathrm{Zr}$ Containing Various Amounts of Dissolved Hydrogen ..............

12. Longitudinal Sections of Castings Poured into Degassed Zircaloy-2 Cans $2 \frac{1}{2} n$ Diameter ..............

13. Photomicrograph of Cast Bond between Zircaloy-2 and Uranium Alloy Core of Casting 1075 Showing Absence of

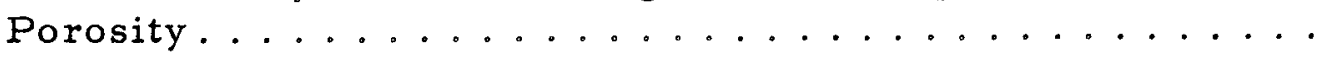

14. Welded Rectangular Zircaloy-2 Can with Sharp Corners ...

15. Zircaloy Can of Rectangular Cross Section with Corner Radii. 


\section{LIST OF FIGURES}

No.

Title

Page

16. Hot-formed Zircaloy-2 Channels Used in Fabricating

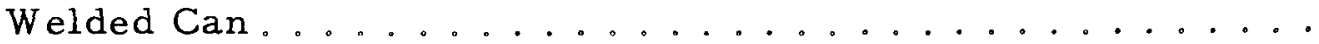

17. Globar Furnace Used for Heating Rectangular Cross sectional Cans with Corner Radii ...............

18. Photomicrograph of Cast Bond in Casting $1021 \ldots \ldots$

19. Casting 1034 Sectioned Showing Core Porosity

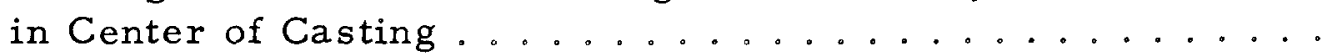

20. Casting 1040 Sectioned to Show Concentrations of Interfacial Porosity at Top of Casting . . . . . . . . . .

21. Casting 1049 Sectioned to Show Lack of Bond Toward Top of Casting Resulting from Embrittled Zircaloy-2 .......

22. Cutaway Sketches of the Two Types of Molds Used for Side

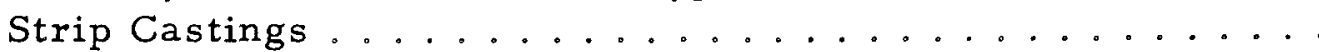

23. Side Strip Casting Showing Uranium Alloy Cast Bonded to

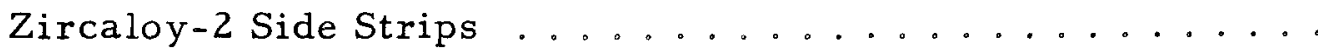

24. Design and Dimensions of Zircaloy-2 Picture Frame

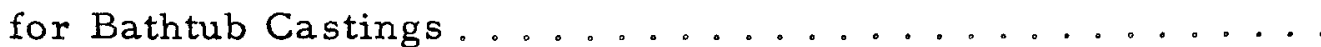

25. Sketch of Bathtub Mold for Casting into Zircaloy-2 Frame...

26. Bottom View of Two Bathtub Castings ............ 


\title{
CASTING URANIUM-5 w/O ZIRCONIUM-1.5 w/O NIOBIUM ALLOYS INTO ZIRCONIUM AND ZIRCALOY-2 CONTAINERS
}

\author{
J. W. Frank and R。E. Macherey
}

ABSTRACT

A series of experimental castings have been made with the object of exploring the proposition that uranium and high uranium alloys could be bonded to zirconium and zirconium alloys by a direct casting method. Unalloyed u ranium and uranium alloyed with $5 \mathrm{w} / \mathrm{o} \mathrm{Zr}$ and $1.5 \mathrm{w} / \mathrm{o} \mathrm{Nb}$ have beencast into zirconium and Zircaloy-2 molds of various shapes and sizes.

Castings made in cans of circular cross section were well bonded and sound, provided the molds were outgassed at elevated temperature before use and proper preheating precautions were observed. Molds of rectangular cross sections, however, did not yield as satisfactory results, mainly because of porosity. The asymmetry of this type of mold probably contributed to the lack of success. Good bonds were obtained between uranium and zirconium by casting into graphite molds lined on opposite sides with zirconium plates.

\section{INTRODUCTION}

The idea of cast bonding a fuel material directly to a can suitable for added strength and corrosion resistance has intriguing possibilities. The manufacture of plate-type fuel elements of uranium-rich alloys by roll-bonding techniques $(1)^{*}$ entail enough difficulty to warrant exploration of alternative processes of manufacture. Furthermore, if uranium could be used as a fuel element in a fine-grained cast form, it is believed that great advantages would be gained because of random crystal orientation.(2)

Problems associated with the casting method involve the development of techniques of producing sound castings in some of the unusual shapes desired. Uneven heating, outgassing, and other difficulties must be met in order to avoid the presence of internal voids in the final product.

\footnotetext{
*References at end of paper
} 
As zirconium and other getter metals are frequently desirable as a choice of protective materials for uranium and its alloys, additional care is required to minimize atmospheric contamination of these materials at the necessary casting temperature levels. Some efforts along these lines, part of which were directed toward simple cylindrical shapes of graduated size, and part directed toward more specialized forms, are given in this report.

The earliest known work was that of S. H. Paine(3) who cast uranium at $1300^{\circ} \mathrm{C}$ into thin-walled molybdenum tubes during 1945 . It was found necessary to plate a nickel flash on the molybdenum surface to obtain good bonding.

A. B. Shuck $(4)$ cast zirconium $-4.5 \mathrm{w} / \mathrm{o}$ uranium alloy at $1800^{\circ}-$ $1900^{\circ} \mathrm{C}$ into zirconium and $3 \%$ tin-zirconium cans, heated from $900^{\circ}$ to $1150^{\circ} \mathrm{C}$; he obtained good bonds with zirconium cans only. The bonds formed between the $U$ alloy and the $\mathrm{Zr}-\mathrm{Sn}$ alloy were defective. The defects were characteristic of blowholes at the interface and were attributed to the boiling of tin when the melt was poured against the clad.

Carlson and co-workers(5)at Ames Laboratory, Iowa State College, developed conditions necessary to bond uranium to zirconium and uranium to an uranium alloy by a casting technique. The cast bonding of uranium to nickel and stainless steel was not, however, successfully developed. The work at Ames was confined to circular cross-sectional cans of zirconium with very thin walls ( 1 to 15 mils). There workers found that successful bonds could be obtained only after the proper relationship between pouring temperature, can temperature, and holding time of can at temperature had been established. Too low a can temperature or too short a holding time produced a faulty bond or a lack of bond; too high a can temperature or too long a holding time resulted in complete penetration of the can by the melt. Successful bonds were obtained by pouring uranium at $1250^{\circ} \mathrm{C}$ into zirconium molds 5/8" dia. x $10 \mathrm{mil}$ wall providing a can temperature of $1160^{\circ} \mathrm{C}$ was held for 5 minutes or $1260^{\circ} \mathrm{C}$ for 1 minute. Three minutes at $1260^{\circ} \mathrm{C}$ caused the melt to completely penetrate the can. Somewhat lower temperatures and holding times were found necessary to produce bonding in zirconium cans 1" dia. x $15 \mathrm{mil}$ wall. Zirconium cans with 15-mil walls which were insulated against heat loss were penetrated by uranium poured into them at $1250^{\circ} \mathrm{C}$. Attempts were made to aid the bonding by the plating of the internal surfaces of zirconium cans with nickel or copper. The nickel produced a thin, irregular bond which was apparently unsatisfactory. The copperplated can was found to be bonded unevenly; however, three specimens survived six thermal cycles $\left(150^{\circ}-700^{\circ} \mathrm{C}\right)$ without rupture.

Attempts were made at Ames to cast bond unalloyed uranium to an uranium alloy tube. Uranium at $1250^{\circ} \mathrm{C}$ was poured into uranium $-7.5 \mathrm{w} / \mathrm{o}$ niobium cans, 3/4" O.D. x 1/8" wall, preheated to temperatures ranging from $300^{\circ}$ to $1180^{\circ} \mathrm{C}$. A thin bond was produced at the $1180^{\circ} \mathrm{C}$ can preheat temperatures but none at lower temperatures. 
Experiments conducted at Ames aimed at bonding uranium to nickel and stainless steel tubes were unsuccessful. The diffusion bond formed between $\mathrm{U}$ and $\mathrm{Ni}$ was very wide and very brittle because of the presence of U-Ni compounds. Uranium poured into austenitic stainless steel failed to bond because of complete alloying of the can.

Evans and Allen(6) at MIT were unsuccessful in bonding an U-Fe eutectic a round thin-walled steel tubes due to the attack on the tube if the melt was sufficiently hot to prevent cold shuts in the casting. Some success was obtained by these workers in cast bonding an $\mathrm{U}-\mathrm{Cr}$ eutectic alloy a round Globe iron; however, bonds were not developed by casting this alloy around titanium and zirconium tubes.

Enough prior work had been done to establish feasibility of bonding uranium and uranium alloys to zirconium and zirconium alloys and to emphasize the necessity of close control of the variables involved. The scope of this prior work, however, was limited and bonding conditions were not established for the particular cladding design of interest here. The lack of information upon the physical quality of the cast metal itself resulting from the experiments run made further investigation necessary.

The objective of this program was the development of cast-bonding practices which would produce quality castings well bonded to zirconium and Zircaloy-2 in geometries of interest, with emphasis upon billets suitable for plate-type fuel element fabrication.

Castings in various can designs were made for a variety of purposes. These included the initial feasibility study, effect of variables, simulation of actual fuel element billet castings, and attempts to overcome difficulties encountered along the way. Most of the bonding experiments conducted in this program were carried out using the reference alloy for the Experimental Boiling Water Reactor ( $\mathrm{U}-5 \mathrm{w} / 0 \mathrm{Zr}-1.5 \mathrm{w} / \mathrm{o} \mathrm{Nb}$ ) as the core material and $\mathrm{Zircaloy}-2$ as the cladding, although some work was done with unalloyed uranium and zirconium. This report is divided into sections according to the type of can (mold) employed. These, in order of discussion, are given below:
A. Pin Castings ( $1 / 4$ " to $1 / 2$ " dia.).
B. Castings of Intermediate Diameter ( $1 \frac{1}{4} "$ and $1 \frac{1}{2} "$ dia.).
C. Castings of Large Diameter ( $2 \frac{1}{2}$ " dia.).
D. Rectangular Cross-Sectional Castings.
E. Side Strip and Bathtub Castings. 
PIN-T YPE CASTINGS

The pin-type casting referred to here was one of circular cross section, $1 / 4 "$ to $1 / 2$ " outside diameter. Castings of this size and geometry were made for purposes of exploring the cast-bonding technique on a small, convenient scale and to produce castings which could be made into irradiation specimens.

The fixtures and physical arrangement of these fixtures in the vacuum furnace employed in these experiments were very simple. As shown in Figure 1, the crucible, contained in a graphite or tantalum heater, rested on top of the graphite fixture which contained the zirconium or Zircaloy can. The melts were bottom poured by means of stopper rods and the stream was directed into the small diameter molds by means of a funnel. The heats were carried out in a simple 6" dia. Vycor tube vacuum furnace; power for both melting and mold heating was supplied by a $30-\mathrm{kw}, 10,000-$ cycle motor generator set. This power was induced into both the crucible heater and mold fixture by a single induction coil positioned a round both. The temperature at the top of the zirconium or Zircaloy-2 can (mold) was roughly controlled by the distance the induction coil was placed down from the top of the mold fixture (see Figure 1).

Melting of the uranium core alloy was done either in thoria or magnesia crucibles. The crucibles were all bored for bottom pouring; and these pouring holes were fitted with stopper rods of the same material as the crucible. Only prealloyed uranium melting stock, to eliminate the difficulties associated with dissolving the alloying additions, $\mathrm{Zr}$ and $\mathrm{Nb}$, in the uranium, was used in these experiments.

Three sizes of zirconium and Zircaloy-2 cans were used in these tests. The outside diameters were $1 / 2 ", 3 / 8 "$ and $1 / 4 "$, with corresponding inner diameters of $0.368^{\prime \prime}, 0.277^{\prime \prime}$ and $0.185^{\prime \prime}$. All cans were $3 \frac{1}{2}$ " over-all length, with nominal $1 / 2$ " thick bottoms. The cladding cans were both supported and heated by graphite fixtures shown in Figure 2. These fixtures were $2 \frac{1}{2}$ " O.D. x 1 " I.D. x 3 " deep with $7 / 8$ " thick bottoms. The bottoms were counterbored axially from the inside to the depth of $3 / 8$ " in diameters $1 / 2 ", 3 / 8 "$ and $1 / 4 "$, into which fit the three sizes of cans used. The top of the cans were positioned by covers $1 / 2$ " thick which fit the top of the fixtures. These covers were bored to fit the three sizes of cans. The outboard end of these holes were tapered to act as a funnel in directing the poured metal into the cans. The temperatures at the bottom of the cans were measured by means of thermocouples placed in contact with them. Temperatures of the melts were measured with an optical pyrometer.

Casting data for the sixteen pin-type castings made are summarized in Table I. All castings completely filled the zirconium or Zircaloy-2 molds. With the exception of the first casting made, 1014 , poured into a $1 / 2$ " O.D. 
can at $800^{\circ} \mathrm{C}$, all castings appeared to be well bonded by examination of transverse sections. A decrease in the can diameter of from 2 to 5 mils after pouring was taken as further evidence of bonding. This decrease was the result of the greater contraction of the uranium alloy core than of the cladding during cooling. The principal defect present in the castings was porosity. Of the sixteen castings made, nine were free of porosity (based on $X$-ray radiography and metallography of sections), six exhibited mild porosity, and one showed severe porosity. Photographs of four pin castings are shown in Figure 3. All of the se castings were photographed after approximately $3 / 8$ " had been cut from their tops. Photomicrographs of the core-clad interface of the top section from casting 1027 (3/8" dia.) is shown in Figure 4. The thick diffusion zone (approx.0.001") is clearly visible between the two components. Chemical analyses $(\mathrm{Zr}, \mathrm{Nb}, \mathrm{C}$ and $\mathrm{N}$ ) of some of the castings are contained in Table $\mathrm{II}_{\text {. }}$.

Two of the castings which were considered sound, 1015 and 1020 , were swaged from $1 / 2^{\prime \prime}$ dia.to $0.150^{\prime \prime}$ dia。 at a nominal temperature of $750^{\circ} \mathrm{C}$. For swaging, the castings were preheated 5 minutes in lead maintained at $750^{\circ} \mathrm{C}$ after which reduction was accomplished on a cycle of swaging for 20 seconds followed by a reheat for 20 seconds. Casting No. 1015 swaged satisfactorily, but the bond in casting 1020 was found to be ruptured after swaging. The swaged rod from casting 1015 was heat treated for corrosion resistance $\left(850^{\circ} \mathrm{C} \rightarrow\right.$ water quench), after which surface contamination was removed by centerless grinding to approximately $1 / 8$ " dia. Corrosion testing of $1 / 2 "$ long samples of this rod with the core exposed at these ends did not reveal accelerated bond-line corrosion after 400 hours in static water at $260^{\circ} \mathrm{C}$.

\section{CASTINGS OF INT ERMEDIATE DIAMETER}

Castings in the range of $1 \frac{1}{4} "$ to $1 \frac{1}{2}$ " dia. were made to explore a size which could become attractive for the fabrication of fuel elements. This size range was selected because it could be handled in the 6 " Vycor tube furnace and could be rolled on a $9 "$ mill available. The experimental arrangement of crucible, crucible heater, Zircaloy -2 can and graphite fixture was essentially that shown in Figure 1 and described in the previous section. Two types of Zircaloy- 2 cans were used. One was a seamless type machined from solid bar, and the other type was fabricated from sheet stock by forming and welding.

Four cans were made as weldments from Zircaloy -2 hot rolled into $0.100 "$ sheet and formed into a hollow semicircular cross section, so that two pieces, laid side by side longitudinally, formed a hollow cylinder $1^{\frac{1}{4}}$ " in diameter, 6" long. The edges were so chamfered that a " $V$ " was formed along contiguous edges. Two longitudinal welds by the inert arc-welding process completed the cylinder. A bottom, consisting of a conforming disc of the same sheet Zircaloy, was chamfered and welded in place, using the same welding technique. Argon was allowed to flow through the tube during 
the welding to reduce interior contamination. Eight similar cans were made by machining from solid stock. The fabricated cans were cleaned by abrasive blasting and washed in acetone; the machined cans were merely washed in acetone.

The graphite fixture employed for both support and heating of the $1 \frac{1}{4} "$ O.D.Zircaloy- 2 cans was as shown in Figure 5 . It is to be noted that there is a counterbore in the bottom of the heater into which the can fitted, thus holding the can in the vertical position. A slot was cut radially in the top so as to accommodate two platinum-platinum rhodium thermocouples, one touching the can near the top and the other near the bottom. The can with its heater and thermocouples was placed in a vacuum induction furnace so that the top of the heater was just inside the coil of the furnace. Above the graphite can heater was placed the $\mathrm{MgO}$ crucible with its charge of previously made alloy, stopper rod, graphite heater and connections to the outside. The furnace was evacuated to $0.2 \mu$ and the melting started. The melt was poured at $1320^{\circ} \mathrm{C}$ (optical pyrometer), with the can top at $998^{\circ} \mathrm{C}$, bottom at $770^{\circ} \mathrm{C}$, and at a pressure of $2 \mu$ at the time of pour. The Zircaloy-2 can temperature was measured and recorded by means of a Brown Electronik Recorder. The temperature at the top of the can rose from $998^{\circ} \mathrm{C}$ at the time of pour to $1067^{\circ} \mathrm{C}$ about ten minutes after pouring. This can temperature then dropped to $900^{\circ} \mathrm{C}$ about 20 minutes after pouring. This casting, number 1001 , weighed $1850 \mathrm{gm}$ total, of which $1500 \mathrm{gm}$ was uranium alloy core.

Casting 1001 , cut transversely into five sections, is shown in Figure 6. The core bonded to the clad except at the side weld seams and around the bottom. This lack of bonding was attributed to contamination of the interface in the weld areas. It was felt that a higher can temperature would override this difficulty. In addition to the unbond, porosity was present in the top of the casting.

In a subsequent casting, the zirconium can in its graphite crucible was raised further into the induction coil so that more power would be induced into the graphite heater, thus raising the can temperature. For this heat, 1003, the temperatures at time of pour were:

$$
\begin{array}{lr}
\text { Can Bottom } & 865^{\circ} \mathrm{C} \\
\text { Can Top } & 1115^{\circ} \mathrm{C} \\
\text { Melt } & 1390^{\circ} \mathrm{C}
\end{array}
$$

The maximum temperature the can reached was $1175^{\circ} \mathrm{C}$ at its top. The casting was completely bonded except for part of the periphery of the bottom section. 
The following seven castings were poured into Zircaloy-2 cans machined from bar stock: Data for these and the previous three castings are given in Table III. The melts were poured at approximately $1400^{\circ} \mathrm{C}$ into cans at about $1000^{\circ} \mathrm{C}$ at top and $900^{\circ} \mathrm{C}$ at bottom. All castings were cropped slightly below the core metal level, and all appeared at this surface to be sound and free of pipe. Figure 7 shows casting 1007, as cut. Measurements of the Zircaloy-2 can diameter after casting showed no change in that dimension at the solid Zircaloy -2 bottom; but along the length of can filled with uranium core alloy, the diameter was found to have decreased from 0.016 " to 0.020 ." The positive differential contraction of the core with respect to the clad upon cooling upset the can to smaller diameter. This contraction took place without apparent rupture of the bond.

One of the castings, 1005, was selected for rolling into smaller rod to determine if a precast bond could withstand rod rolling without rupture. This casting was rolled at a nominal temperature of $850^{\circ} \mathrm{C}$ to $3 / 8^{\prime \prime}$ diameter in a sequence of hand round passes on a $9 "$ mill. The casting was rolled without a protective jacket; preheat for and reheat during rolling was done in a triple carbonate salt bath (E. F.Houghton Co. No. 235). Complete details of rolling are discussed elsewhere.(1) Photomicrographs of the bond area of casting 1005 in the as-cast condition and after rolling from $1 \frac{1}{4}{ }^{\prime \prime}$ dia. to $0.318^{\prime \prime}$ dia. at a nominal temperature of $850^{\circ} \mathrm{C}$ (water quenching after final pass) are shown in Figure 8. For these particular working conditions, the bond layer grows at about the same rate as it is reduced by working.

The rolled rod was cut into lengths and heat treated for corrosion resistance. Coxrosion resistance to water of the $U-5 \mathrm{w} / \mathrm{o} \mathrm{Zr}-1.5 \mathrm{w} / \mathrm{o}$ $\mathrm{Nb}$ alloy can be obtained by developing a supersaturated alpha structure by water quenching from the gamma phase at $850^{\circ} \mathrm{C}$.(7) A salt bath (Houghton 235) was used to heat the bare specimens to the gamma solution temperature. Hardness values of this alloy differ widely depending upon mechanical and thermal history. The hardness of this alloy as cast (very slow cool) ran 33 on the Rockwell "C" scale. A hardness of $R_{C} 51$ developed after air cooling a rod rolled at $850^{\circ} \mathrm{C}$; and this hardness level was reduced to $R_{c} 39$ by water quenching after reheating to the gamma phase. In addition to these changes in hardness level, typical of an age-hardenable alloy, this alloy was found to be susceptible to quench cracking. Heavy section cracked upon water quenching while some smaller quenched sections developed cracks in the core alloy upon standing at room temperature overnight.

Specimens 3/8" long were corrosion tested with core alloy exposed to static degassed water at $260^{\circ} \mathrm{C}$ in an autoclave for periods of one and two weeks. After one week the bond line appeared to be preferentially corroded; after two weeks, bond line failure was complete, rupturing the clad longitudinally. 
The good results obtained on bonding uranium alloy to the $1 \frac{1}{4}$ " dia. can duplicated the satisfactory bonds obtained much earlier by casting unalloyed uranium into $1 \frac{1}{2} "$ dia. zirconium cans.

\section{CASTINGS OF LARGE DIAMETER}

The casting of uranium core alloy into cans of large diameter was pursued as a means of overcoming a bonding deficiency encountered in rolling flat fuel plates on flat rolls. In the roll cladding of unalloyed uranium with zirconium, it was found that simple flat rolling of rectangular cladding billets did not lead to the development of bonds between the sides of the $U$ core and the zirconium side plates. This gap between core and side plate is shown in Figure 9. It was speculated at the time this difficulty was observed that, by prebonding the billet before rolling, the problem would be solved. Cast bonding was considered as a possible method. The round cross-sectional geometry discussed in this section was selected because of simplicity in the fabrication of the Zircaloy-2 can and establishment of casting condition. These billets were intended for fabrication into flat plate by a sequence of oval pass and flat rolling operations.

The scale-up to $2 \frac{1}{2}$ " dia. cans made it necessary to use a furnace larger than the 6" Vycor tube furnace employed for the smaller cans. Melting was done in two vacuum furnaces. One was a $12^{\text {" }}$ quartz tube furnace pumped with a $10^{\prime \prime}$ condensing oil diffusion pump and a $100-\mathrm{cm}$ mechanical pump; the other was a $36^{\text {" }}$ steel shell furnace pumped by a $16^{\text {"fractionating }}$ oil diffusion pump backed up with an oil ejector pump and a 100 -cfm mechanical pump. Both furnaces were of the same melting capacity of about $100 \mathrm{~kg}$ of uranium.

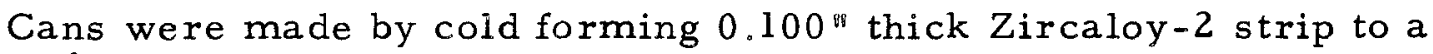

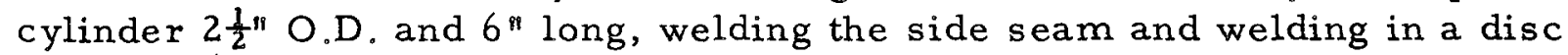
bottom $1 / 4^{\text {p }}$ thick. The can was heated inductively in a graphite heater, of cylindrical form, in which the bottom of a can was held tightly, the remainder being surrounded by an annular cavity. There were six such castings made, all of which were well bonded, but showed porosity at the interface.

In an attempt to reduce porosity, the cans for castings 1043 and 1044 were machined inside to almost complete cleanup, on the theory that the surface had been damaged on hot rolling. Porosity was less than in the earlier castings in the case of casting 1043 but it was still a disqualifying feature. Casting 1044 was as bad as the first four. Figure 10, showing casting 1044, is about average in porosity. Casting data are shown in Table IV. Cooling curves showed that in all cases the can temperatures were significantly higher after the uranium alloy was poured into them. The significance of this fact will be brought out in the final section. 
The difficulties were mainly due to porosity, internal spongy areas, and brittle Zircaloy. This Zircaloy embrittlement was considered to be responsible for the lack of bonding in several cases. Embrittlement with or without coincident bond rupture was successfully ameliorated by higher vacua during melting and subsequent cooling. Differential can heating raised the spongy section to a place where cropping would be feasible. This left interfacial and other porosity the most serious remaining difficulty.

A look at available free energy data made the evolution of any gases except hydrogen rather improbable, at least for the temperatures involved. In previous experiments, the can was heated to about $1000^{\circ} \mathrm{C}$ and the uranium alloy at about $1400^{\circ} \mathrm{C}$ was poured into it. This should make the interface reach a high temperatureat the moment it was wetted by thealloy and initial. solidification took place. According to Schwartz and Mallet,(8) whose data are reproduced in Figure 11 , if the rate of hydrogen release were not rapid, a rise of $300^{\circ} \mathrm{C}$ or more might release a burst of hydrogen. Further, an oxide coating, even if very thin, might interfere with passage of hydrogen through the interface, (9) and the surface film is notabsorbed into the lattice below $800^{\circ} \mathrm{C}$ at any appreciable rate. It is to be noted that in previous experiments the time of heating above $800^{\circ} \mathrm{C}$ was relatively short.

Under these circumstances, a new series of experiments was started,

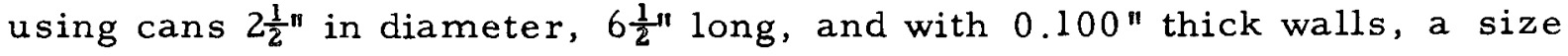
where excess porosity was previously experienced. These cans were outgassed at $1500^{\circ} \mathrm{C}$ for four hours in a vacuum of less than $0.08 \mu$ (usually $0.02 \mu$ ) and cooled under equally good vacuum to room temperature. These cans were kept in an oven at $100^{\circ} \mathrm{C}$, until placed in the melting equipment, usually within one hour. Casting data are given in Table IV.

Four such melts were made and sectioned; these are shown in Figure 12. It is to be noted that all are completely free of porosity except casting 1075, where a single bubble is found along the side wall. Figure 13 shows a micrograph of casting 1075, selected at random. There is no evidence of surface porosity on a microscopic scale.

The tin in the Zircaloy-2 could be vaporized upon being heated by the melt being poured against it, causing blowholes. At the pouring temperature, tin has a vapor pressure of about 500 microns. This vapor pressure is greatly reduced by alloying with zirconium to an estimated 10 microns. At the furnace pressures employed a head of uranium of approximately one mil is sufficient to condense tin vapor. At the time it was considered unlikely that the tin in Zircaloy caused the trouble. The outgassing of Zircaloy could have produced tin depletion at the surface, but at the time these experiments were made this was not considered as the cause of improvement in the casting. 
The results obtained on the cylindrical castings appeared to justify a change in geometry which could be rolled directly into a fuel plate (the conversion of a round billet into a flat plate by oval and flat rolling having been found unattractive).(1) The geometry selected was the rectangular, instead of the square, because of the greater stability of a rectangular shape in flat rolling.

The first rectangular cans were made up of flat plates joined by shielded arc welding. The outside dimensions of the Zircaloy-2 cans fabricated were 4 " wide $\times 1.04^{\prime \prime}$ thick $\times 14^{\text {" }}$ long. The major walls (4") of the can were 0.100 " thick; the minor walls $\left(1.04^{\prime \prime}\right)$ were $1 / 4$ " thick; and the bottom of the can was 3/8" thick. A completed can is shown in Figure 14.

In the circular can casting, the cans were heated by radiation from circular graphite fixtures which were in turn heated by induction. This method was not considered to be good for rectangular cans because of the difficulty in heating a rectangular section uniformly by the same coil used for melting. Nichrome wire resistance-type heating elements were used on this first series of castings. Platinum-platinum rhodium thermocouples were so placed as to touch the bottom and top of the can; continuous temperature records were made. In general, the practice was to regulate the auxiliary power so that both melt and can reached the desired temperature simultaneously. The alloy was then poured, power turned off, and the diffusion pumps shut off within 15 minutes afterward. Castings 1011, 1013, 1017, and 1019 were made using this technique. Casting data for this series are contained in Table V.

The Zircaloy- 2 can used in casting 1011 was heated by flat platetype wire resistance heating elements. These elements were clamped against the major walls of the can to prevent bulging when filled by the melt. Failure of the heating elements caused by reaction of the element and can resulted in low can temperature at time of pour. The complete lack of bond in this casting was attributed to the low can temperature. The casting was removed from the can and the can reused for casting 1018 , after grit blasting. To overcome this difficulty, casting 1012 was made using cylindrical heating elements not supporting the can. The can bulged badly on casting. Original practice was again used for the balance of the castings. Casting 1013 did not have a bond at the edges, and microscopy showed poor bonding along the sides. At the time this effect was assigned to the sharp corner and was the reason for redesign to cans with large corner radii, described later. Regardless, this casting was rolled to a flat plate and appeared to have satisfactory bonding.

Castings 1017 and 1018 were made in a similar way. Casting 1017 was also poorly bonded near the top and was porous at the interface. Casting 1018 was completely unbonded. It is to be remembered that this can was 
heated twice. It will be shown later that there is reason to believe that a bond was established and then subsequently was broken due to embrittlement of the zirconium and to differential contraction of the two metals.

The major difficulties with the sharp-cornered rectangular can were the lack of bond, principally at the edges, and the internal unsoundness of the cast metal. The lack of bond at the edges was attributed to the triaxial stress pattern developed at the edges by the positive differential contraction of core with respect to clad upon cooling, the accentuated stress raising the sharp corner, and the inability of the can to contract at the corner with the core alloy. Both these conditions were reasoned to be relieved at least partially by the rounding of the can corners.

The can design selected was as shown in Figure 15. This can was made by hot forming two channels (see Figure 16) and joining two channels by shielded arc welding. The cans were made from 0.100 " thick strip and $1 / 4$ " thick bottom plates.

The lack of thermal gradient in the can was considered the likely cause of internal unsoundness of the previous rectangular castings. These cans were heated to a very low thermal gradient (see Table VI). Three methods of can heating were employed in this series of castings. The first method was a duplicate of the one previously used (wire resistance elements) for purposes of comparison with the other two methods. These other methods were selected for purposes of developing a decreasing can temperature from top to bottom. The methods were induction using a graphite heater and Globar heating elements.

Castings 1021,1033 and 1034 were heated by "Hevi-Duty" flat heating elements, supporting the flat side of the can. Castings 1038,1040 and 1042 were inductively heated by a conforming graphite heater placed to be partially in the inductive zone of the furnace. Castings 1045 to 1054, inclusive, were heated in the "Globar" furnace shown in Figure 17. Twelve "Globar" elements were used in three sets of four, to obtain a temperature gradient from bottom to top. The four bottom elements made up a set, as did the center and top four. In order to obtain proper resistance for the voltage available, each two "Globars" were connected in series. Two such series circuits were connected in parallel to the power supply by means of a Variac. An ammeter and voltmeter were connected to each of the Variac circuits to measure the power supplied. Earlier castings had two thermocouples attached, top and bottom. Later castings utilized three thermocouples, the additional thermocouple being placed at the approximate center of the can.

Casting 1021 appeared to be well bonded, as shown by the micrograph in Figure 18. However, gammagraphs showed internal porous areas in all of these castings, of which that shown in Figure 19 is typical. This porosity was similar to that found in the melts poured into the square-cornered cans 
heated similarly. This condition was assumed to be the result of a freezing direction normal to the can walls developed by insufficient thermal gradient in the mold.

Castings inductively heated had excessive interfacial porosity, of which Figure 20 is typical. Temperature control was difficult, and can temperatures were relatively high, particularly after pouring. A reading of $1440^{\circ} \mathrm{C}$ was obtained from the top thermocouple of casting 1033 about 30 seconds after the beginning of the pouring. An explanation for this porosity has been given previously in the discussion of hydrogen liberation.

Castings 1045 and 1046 were poured into Zircaloy-2 cans upon which attempts were made at outgassing. Each can in turn was heated to $1000^{\circ} \mathrm{C}$ and held at that temperature overnight in the vacuum furnace loaded for the heat. The next day the melt was made and poured into the can. This procedure was designed to remove hydrogen and cure the interfacial poros ity. Unfortunately, the vacuum obtained was so poor that contamination and embrittlement of the Zircaloy-2 occurred; bonding was a failure in both castings.

Examination of the surfaces of the core and clad lead to speculation because of appearance that fracture took place elsewhere than at the original interface. Spectrographic examination of the mating surface of the core alloy and the mating surface of the Zircaloy-2 clad revealed these two surfaces to be essentailly pure zirconium. Apparently the bond was formed upon casting but, due to embrittlement of the Zircaloy, a fracture developed in the Zircaloy because of its low ductility and inability to yield with the contracting core alloy.

On the premise that Zircaloy contamination was the cause of poor results, attempts were made to restrict time the can was at temperature before pouring. Castings 1047 to 1050 were cast with the Zircaloy can heated as rapidly as possible after the uranium alloy was melted. Figure 21 , showing casting 1049, is typical of this set of castings. The bonding is poor near the top of the casting, the Zircaloy is embrittled, but the spongy area has been raised substantially by the better thermal gradient. Vacua obtained were progressively worse.

In order to improve the vacuum and stop Zircaloy embrittlement, the furnace was overhauled. Practice was also changed in that, before casting, the bottom two can heater circuits were cut off and the top circuit operated at maximum power. Further, the best vacuum was maintained until the casting had cooled below $500^{\circ} \mathrm{C}$, to avoid contamination during cooling. Radiography showed a slight rise in the porous area, with a resultant increase in usable portion. Zirconium ductility was improved as well as the bonding. Casting data are shown in Table VI. Analysis of embrittled Zircaloy is in Table VII. 
Sections of the Zircaloy cans from castings 1045 and 1046, where Zircaloy embrittlement was found, were machined free from adherent uranium alloy and outer surface. These were placed in autoclaves with water at $260^{\circ} \mathrm{C}$ for one week. At the end of this period, a white corrosion coating was found. Pieces of the can from casting 1051 and 1052 were cleaned up in the same way. These were autoclaved with water for 2000 hours at $290^{\circ} \mathrm{C}$. The specimen from casting 1051 had a smooth adherent black coating, indicating satisfactory corrosion resistance. The other specimen had an incipient grey color. These latter specimens were from castings cast and cooled under improved vacuum. Work was discontinued on this type of casting due to temporary abandonment as a means of fuel fabrication.

\section{SIDE STRIP AND BATHTUB CASTINGS}

The partial prebonding of cladding billets is discussed in this section. Enough difficulties were encountered in the cast bonding of an uranium core alloy into Zircaloy-2 cans to warrant consideration of other means of solving the then-existent side bonding and end closure problems. The approach here was to utilize the cast-bonding technique only where necessary and to rely upon roll bonding to complete the cladding of the fuel plate. Two methods were proposed. One, aimed at overcoming the side bonding problem, was called the side strip casting; the other, aimed at the solution of both the side bonding and end closure problems, was referred to as a "bathtub" casting.

The side strip castings were made simply by pouring core alloy into a rectangular mold cavity bounded on one set of opposite sides by graphite and the other opposite set by the Zircaloy -2 cladding. In comparing this casting procedure with the closed rectangular can approach, the side strip casting was designed to eliminate: (1) the necessity of maintaining close thickness tolerances in casting for the control of finished dimensions and camber in the plates rolled from cast billets, (2) the tensile stress perpendicular to the core - side plate interface caused by differential contraction of core and clad, (3) the stress at the Zircaloy mold corners by eliminating these corners, and (4) the necessity of fabricating and joining a Zircaloy mold.

Work carried out at a much earlier date gave some initial confidence in this procedure. These early experiments consisted of casting unalloyed uranium between side plates of zirconium. The mold employed was such that two zirconium strips, 1/16" thick, could be inserted, giving a mold cavity bounded on two sides by zirconium and on the other two by graphite. The uranium was melted in a graphite crucible, using a graphite stopper rod, and bottom poured into the mold. The vacuum ranged from $8 \times 10^{-4}$ to $1 \times 10^{-6} \mathrm{~mm}$ of $\mathrm{Hg}$. The casting appeared sound and the zirconium strips had adhered to the uranium. 
In the later series of castings two changes were made in the earlier practice. First, an uranium alloy was used; second, Zircaloy-2 was substituted for zirconium as the clad. Two types of graphite molds, which differed in the manner in which the Zircaloy-2 strips were supported, were used in these castings. The two types of molds are sketched in Figure 22. In the Type I mold, the sides of the Zircaloy-2 strips fitted into slots running the entire length of the mold. In the Type II mold, the Zircaloy-2 strips, which were narrower than the mold, were positioned by slots in the bottom plug and held apart at the top by spacer bars. The Type I mold was used to produce casting L-86 and was then abandoned, because of separation of core and clad along the edges caused by the differential contraction of uranium and graphite. The Type II mold, in which the Zircaloy-2 strips were held at top and bottom, gave much better results. Except at the very top, which usually had to be cropped anyway, and at the bottom, which had to be machined for an end plug, the Zircaloy-2 side strips were free to move with the core contraction in the major transverse direction.

The melts for this series of castings were made in $\mathrm{MgO}$ crucibles heated by means of graphite heaters. The molds were heated by both conduction from the crucible and induction from the main power source. Melt data for this series of castings are contained in Table VIII. In general, all side strip castings with the exception of L-86 we re well bonded. Wide variance in the soundness of the cast metal was noted. The first castings made under more or less the same conditions vacillated between soundness and unsoundness. Of particular interest, however, is the consistent improvement in internal quality in billets L-140, L-141, L-1 48 and L-149. These billets were cast into molds which were placed inside zirconia tubes. The higher mold temperature resulting from this insulation was presumed to be the major contributor to quality improvement. A typical side strip casting is pictured in Figure 23. Processing of these side strip castings into cladding billets and fabrication of the billets into plates are discussed elsewhere.(1)

The "bathtub" type casting was designed to prebond both sides and ends of the core to the cladding and eliminate the necessity of bonding the end plugs to the side strips. The Zircaloy -2 cladding for these castings is sketched in Figure 24. This cladding is simply a picture frame in which the ends are considerably thicker than the sides and the inboard sides of the ends have "V's" cut into them. For casting, a Zircaloy ring fabricated of $1 / 8$ " thick $\times 1 / 2$ " wide strip by forming to the hole dimensions and welding was joined to one side of the cladding. This ring was indented to allow for overfilling, which acted as a shrinkage reservoir and a spectrographic sample after removal. The Zircaloy cladding fit into a graphite mold which closed the bottom of the cladding as shown in Figure 25. The internal surfaces of the mold were washed with a $\mathrm{CaO}$ slurry and dried in attempt to eliminate attack by the melt. A thermocouple was attached to the mold so that temperature measurements could be made. 
Three sizes of castings were made of this general type. The Zircaloy -2 cladding frame sizes are shown in Figure 24 . The cavity in the Size A frame was $4 \frac{1}{4} "$ long $\times 2 \frac{1}{8} "$ wide $\times 11 / 16^{\prime \prime}$ deep; the Size B frame was $7 \frac{3}{8} "$ long $x$ " wide $\times 1 \frac{1}{4}$ " deep; and the Size C frame was 12 "long $x 4 \frac{1}{4}$ " wide $x$ lat" deep, all outside dimensions.

Six castings, numbers 1055 to 1060 inclusive, were made in the Size A frame. Mold temperatures were approximately $1150^{\circ} \mathrm{C}$, and the uranium alloy was poured at about $1350^{\circ} \mathrm{C}$. The vacuum at the time of pouring ranged between 0.2 and 0.9 micron, except for casting 1058, which was poured at about 500 microns during loss in vacuum due to a cracked sight glass. All castings were porous at the core clad interface except, strangely enough, casting 1058 , in which the vacuum was lost.

The Size B frame was used for twelve castings, numbers 1061 to 1072 inclusive. The mold temperatures varied between $990^{\circ} \mathrm{C}$ and $1177^{\circ} \mathrm{C}$, a somewhat greater range than for the smaller size castings. The melts, however, were found in a much narrower temperature range, $1390^{\circ} \mathrm{C}$ to $1420^{\circ} \mathrm{C}$. The vacuum in no case was poorer than $0.5 \mathrm{micron}$, but was more often 0.3 micron. All castings had porous interfaces to some extent. Castings $1061,1064,1066,1067$, and 1070 were better than average, but 1062 , and 1063 and 1072 were poorer than average with no apparent correlation to melt conditions. Figure 26 is typical of the appearance of the castings. It shows casting 1064, one of the better ones, and 1068, typical of the poorer.

One casting was made in the largest size frame, Size C. Because of its large size it could not be positioned within the induction coil of the furnace; consequently the temperature of the frame was only $890^{\circ} \mathrm{C}$ at the time of pour so the melt was heated to $1490^{\circ} \mathrm{C}$ in attempt to compensate for the lower frame temperature. The vacuum was about 1 micron at the time of pouring. This casting was also porous. In view of the unsatisfactory results obtained with all these "bathtub" castings, the inclusion of complete casting data is not considered warranted.

\section{CONCLUSIONS}

Uranium alloyed with $5 \mathrm{w} / \mathrm{o} \mathrm{Zr}, 1.5 \mathrm{w} / \mathrm{o} \mathrm{Nb}$ was successfully cast bonded to Zircaloy-2 cylindrical cans as small as $1 / 4 "$ O.D., 3/16" bore, $3 \frac{1}{2} "$ long. There was little difficulty in filling of the cans provided the can temperature was sufficiently high. This uranium alloy was cast into Zircaloy-2 cans 1.5" O.D. x 1 " I.D. with good bonding, provided can temperatures were above $750^{\circ} \mathrm{C}$. One such casting was reduced to $0.318^{\prime \prime} \mathrm{di}-$ ameter by rolling in hand round passes at a nominal temperature of $850^{\circ} \mathrm{C}$ without loss of bond. 
Rectangular Zircaloy-2 cans $1 \frac{5}{8} " \times 2 \frac{5}{8} " \times 0.100 "$ wall with corner radii were cast to a depth of about 8 " with the ternary uranium alloy. Unbonding, interfacial porosity, and internal shrinkage were encountered. Castings were also made between side strips only and in picture frame, "bathtub" molds. The same problems were encountered with these castings.

The unbonding encountered in the castings was found in general to be a bond which had ruptured after forming. Experiments which were performed in vacuum poorer than 1 to 2 microns embrittled the Zircaloy through the absorption of oxygen and nitrogen such that, in extreme cases, the bond was ruptured in the Zircaloy after forming because of the inability of the Zircaloy to yield with the contracting core.

Interfacial porosity was a serious problem not fully solved. This porosity apparently resulted from gas or vapor evolution from the mold. Higher mold temperatures were an aid and outgassing of the mold prior to use helped. The function of higher mold temperature was probably increased freezing time which permitted escape of gas or vapor. Outgassing of the mold prior to use was intended to remove hydrogen. Unfortunately this practice could have removed tin from the Zircaloy. The internal porosity never was completely removed but careful establishment of a thermal gradient in the mold raised the porous area to the top of the casting.

These experiments have shown that the $\mathrm{U}-\mathrm{Zr}-\mathrm{Nb}$ alloy can be cast bonded to Zircaloy-2 with varying mass ratios of Zircaloy and uranium. Successful bonding and quality of the cast billet were found to be dependent upon many factors. In a practice such as this, the casting procedure must yield a near perfect casting, since remedial measures such as scalping cannot be performed. In the design of the practice, conditions must be es tablished to obtain sound castings simultaneously with establishing conditions condusive to bonding. These conditions in all respects are not identical. Since elevated temperature of the Zircaloy can were necessary, exceptionally good vacuum for furnaces of this type must be maintained for contamination of the Zircaloy by atmospheric constitutents not only reduce ductility but seriously reduce corrosion resistance.

Although cast bonding appeared attractive and potentially capable of simplifying billet preparation, the conditions necessary to achieve bonding are costly and difficult to establish.

\section{ACKNOW LEDGEMENTS}

The authors are indebted to G. V. Bennett and J. E. Baird under whose direction early work indicating feasibility of the cast bonding process was done. The authors wish to express appreciation to M. Dimenn for carrying out many of the details of experiments, as well as to J. A. Goleb and $R$. W. Bane of the Chemistry Division for analyses. 


\section{REFERENCES}

1. C. H. Bean, R. E. Macherey anả J. R. Lindgren, "Roll Cladding UraniumZirconium and Uranium-Zirconium-Niobium Alloys with Zircaloy-2 for Plate Type Fuel Elements," ANL-56́28 (April 1958).

2. J. H. Kittel, S. Greenberg, S. H. Paine, and J. E. Draley, "Effects of Irradiation on Some Corrosion Resistant Fuel Alloys," Nuclear Science and Engineering, Vol. 2, No. 4, July 1956.

3. S. H. Paine, unreported work.

4. A. B. Shuck," Zrclad Zirconium-Uranium Alloy Rod for Heat Thru-Put Test," ANL-5089 (April 17, 1952).

5. O. N. Carlson, P. Chiotti, and P. E. Armstrong, "Ames Quarterly Summary Reports," ISC-287, 314, 346, 389, 426, 452, 468 and 532 (1952 to 1954).

6. R. O. Evans and L. R. Allen, "Technical Progress Reports, MIT Metallurgical Project," MIT-1111, 1113, 1114 and 1115 (1953).

7. J. E. Draley and W. E. Ruther, "The High Temperature Aqueous Corrosion of Uranium Alloys Containing Minor Amounts of Niobium and Zirconium," ANL-5530 (October 1956).

8. C. M. Schwartz and M. W. Mallet, "Equilibrium Pressure of Hydrogen over Zirconium Containing Various Amounts of Dissolved Hydrogen," Trans ASM, 46, 640 (1954).

9. J. E. Draley, private communication. 
Table I

CASTING DATA FOR SMALL CYLINDRICAL CANS (PIN CASTINGS).

\begin{tabular}{|c|c|c|c|c|c|c|c|}
\hline $\begin{array}{l}\text { Casting } \\
\text { No. }\end{array}$ & $\begin{array}{l}\text { Can } \\
\text { O.D. } \\
\text { in. }\end{array}$ & $\begin{array}{c}\text { Can } \\
\text { Material }\end{array}$ & Crucible & $\begin{array}{l}\text { Pour } \\
\text { Temp, } \\
{ }^{\circ} \mathrm{C}\end{array}$ & $\begin{array}{l}\text { Can } \\
\text { Bottom } \\
\text { Temp, }{ }^{\circ} \mathrm{C}\end{array}$ & $\begin{array}{l}\text { Vacuum at } \\
\text { Pour } \\
\text { microns }\end{array}$ & Remarks \\
\hline 1014 & $1 / 2$ & Zircaloy-2 & $\mathrm{ThO}_{2}$ & 1500 & 800 & 0.5 & $\begin{array}{l}\text { Sectioned, bottom unbonded, } \\
\text { porosity in mid-section. }\end{array}$ \\
\hline 1015 & $1 / 2$ & Zircaloy-2 & $\mathrm{ThO}_{2}$ & 1400 & 1063 & 0.6 & $\begin{array}{l}\text { Sound at top. Swaged to } \\
1 / 8^{\prime \prime} \text { dia. }\end{array}$ \\
\hline 1016 & $1 / 2$ & Zircaloy-2 & $\mathrm{ThO}_{2}$ & 1400 & 1092 & 0.5 & $\begin{array}{l}\text { Sectioned, well bonded, } \\
\text { small top shrink. }\end{array}$ \\
\hline 1019 & $3 / 8$ & Zircaloy-2 & $\mathrm{ThO}_{2}$ & 1450 & 1085 & 0.1 & $\begin{array}{l}\text { Can heated previously during } \\
\text { heat not poured. Sectioned, } \\
\text { well bonded, some porosity. }\end{array}$ \\
\hline 1020 & $3 / 8$ & Zircaloy-2 & $\mathrm{ThO}_{2}$ & 1420 & 1131 & 0.2 & $\begin{array}{l}\text { Can heated previously during } \\
\text { heat not poured. Radiographed, } \\
\text { appeared sound. }\end{array}$ \\
\hline 1022 & $1 / 4$ & Zircaloy-2 & $\mathrm{ThO}_{2}$ & 1400 & 1190 & 1 & $\begin{array}{l}\text { Radiographed \& sectioned, } \\
\text { appeared sound \& well bonded. }\end{array}$ \\
\hline 1023 & $1 / 4$ & Zircaloy-2 & $\mathrm{MgO}$ & 1405 & 1190 & 350 & $\begin{array}{l}\text { Radiographed, top cropped, } \\
\text { appeared sound \& well bonded. }\end{array}$ \\
\hline 1024 & $1 / 4$ & Zircaloy-2 & $\mathrm{MgO}$ & 1415 & 1200 & 35 & $\begin{array}{l}\text { Radiographed, top cropped, } \\
\text { appeared sound \& well bonded. }\end{array}$ \\
\hline 1025 & $1 / 2$ & Zircaloy- 2 & $\mathrm{MgO}$ & 1400 & - & 120 & $\begin{array}{l}\text { Radiographed, top cropped, } \\
\text { slight porosity at bottom. Well } \\
\text { bonded. }\end{array}$ \\
\hline 1026 & $3 / 8$ & Zircaloy- 2 & $\mathrm{MgO}$ & 1400 & -- & 90 & $\begin{array}{l}\text { Radiographed, top cropped, } \\
\text { appeared sound \& well bonded. }\end{array}$ \\
\hline 1027 & $3 / 8$ & Zircaloy -2 & $\mathrm{MgO}$ & 1400 & 1205 & 90 & $\begin{array}{l}\text { Radiographed, top cropped, } \\
\text { appeared well bonded, small } \\
\text { cavity at bottom. }\end{array}$ \\
\hline 1028 & $3 / 8$ & Zr Crystal Bar & $\mathrm{MgO}$ & 1400 & 1173 & 35 & $\begin{array}{l}\text { Radiographed, top cropped, } \\
\text { appeared sound \& well bonded. }\end{array}$ \\
\hline 1029 & $3 / 8$ & Zr Crystal Bar & $\mathrm{MgO}$ & 1400 & 1152 & 30 & $\begin{array}{l}\text { Radiographed, top cropped, } \\
\text { appeared well bonded, small } \\
\text { cavity at bottom. }\end{array}$ \\
\hline 1030 & $3 / 8$ & Zr Crystal Bar & $\mathrm{MgO}$ & 1400 & 1153 & 250 & $\begin{array}{l}\text { Radiographed, top cropped, } \\
\text { appeared sound \& well bonded. }\end{array}$ \\
\hline 1031 & $3 / 8$ & Zr Crystal Bar & $\mathrm{MgO}$ & 1400 & 1181 & 40 & $\begin{array}{l}\text { Radiographed, top cropped, } \\
\text { appeared well bonded, small } \\
\text { cavity at bottom. }\end{array}$ \\
\hline 1032 & $1 / 4$ & Zircaloy-2 & $\mathrm{MgO}$ & 1400 & 1182 & 50 & $\begin{array}{l}\text { Radiographed, top cropped, } \\
\text { appeared sound \& well bonded. }\end{array}$ \\
\hline
\end{tabular}

*All cans $3 \frac{1}{2} "$ long. 
Table II

ANALYSES OF URANIUM ALLOY IN PIN CASTINGS*

\begin{tabular}{|c|c|c|c|c|c|}
\hline $\begin{array}{c}\text { Casting } \\
\text { No. }\end{array}$ & $\begin{array}{l}\mathrm{Nb} \\
\mathrm{w} / \mathrm{O}\end{array}$ & $\begin{array}{l}\mathrm{Zr} \\
w / 0\end{array}$ & $\begin{array}{c}\mathrm{C} \\
\mathrm{ppm}\end{array}$ & $\begin{array}{c}\text { N } \\
\text { ppm }\end{array}$ & Remarks \\
\hline $\begin{array}{l}1014 \\
1015 \\
1016 \\
1019 \\
1020 \\
1022 \\
1023 \\
1024 \\
1025 \\
1026 \\
1027 \\
1028 \\
1029 \\
1030 \\
1031 \\
1032\end{array}$ & $\begin{array}{l}1.75 \\
1.75 \\
1.87 \\
0.62 \\
1.68 \\
1.78 \\
1.45 \\
1.65\end{array}$ & $\begin{array}{l}3.32 \\
5.33 \\
4.92 \\
6.94 \\
7.63 \\
5.92 \\
4.78 \\
5.79 \\
5.62\end{array}$ & $\begin{array}{r}13 \\
21 \\
204 \\
330 \\
130 \\
32 \\
36 \\
28\end{array}$ & $\begin{array}{r}48 \\
10 \\
24 \\
13 \\
150 \\
<10 \\
<10 \\
<10 \\
<10\end{array}$ & $\begin{array}{l}\text { Not Analyzed } \\
\text { Not Analyzed } \\
\text { Not Analyzed } \\
\text { Not Analyzed } \\
\text { Not Analyzed }\end{array}$ \\
\hline
\end{tabular}

* Samples taken from top of castings.

Table III

CASTING DATA FOR $1 \frac{1}{4} "$ O.D. $x 1 "$ I.D. CANS

\begin{tabular}{|c|c|c|c|c|c|c|}
\hline \multirow{2}{*}{$\begin{array}{l}\text { Casting } \\
\text { No. }\end{array}$} & \multirow{2}{*}{$\begin{array}{l}\text { Type of } \\
\text { Can }(a)\end{array}$} & \multirow{2}{*}{$\begin{array}{l}\text { Pouring } \\
\text { Temp, } \\
{ }^{\circ} \mathrm{C}\end{array}$} & \multicolumn{2}{|c|}{ Can Temp, (b) } & \multirow{2}{*}{$\begin{array}{l}\text { Vacuum at } \\
\text { Pour } \\
\text { microns }\end{array}$} & \multirow{2}{*}{ Remarks } \\
\hline & & & $\begin{array}{l}\text { Top } \\
{ }^{\circ} \mathrm{C}\end{array}$ & $\begin{array}{l}\text { Bottom } \\
{ }^{\circ} \mathrm{C}\end{array}$ & & \\
\hline 1001 & Welded & 1320 & 1000 & 770 & 2 & $\begin{array}{l}\text { Sectioned, unbond in weld } \\
\text { area. Core porous }\end{array}$ \\
\hline 1002 & Welded & & 990 & 700 & & $\begin{array}{l}\text { Furnace leaked, melt not } \\
\text { poured. }\end{array}$ \\
\hline 1003 & Welded & 1390 & 1115 & 865 & 0.7 & $\begin{array}{l}\text { Sectioned, unbonded at } \\
\text { bottom. Core sound. }\end{array}$ \\
\hline 1004 & Seamless & 1410 & 940 & 920 & 1 & $\begin{array}{l}\text { Clad machined off, very few } \\
\text { blowholes at core-clad } \\
\text { interface. }\end{array}$ \\
\hline 1005 & Seamless & 1390 & 1075 & 935 & 0.8 & $\begin{array}{l}\text { Top cropped, sound \& well } \\
\text { bonded. }\end{array}$ \\
\hline 1006 & Seamless & 1395 & 1040 & 905 & 1 & $\begin{array}{l}\text { Top cropped, sound \& well } \\
\text { bonded. }\end{array}$ \\
\hline 1007 & Seamless & 1400 & 1025 & 905 & 0.9 & $\begin{array}{l}\text { Top cropped, sound \& well } \\
\text { bonded. }\end{array}$ \\
\hline 1008 & Seamless & 1400 & 1040 & 925 & 0.7 & $\begin{array}{l}\text { Top cropped, sound \& well } \\
\text { bonded. }\end{array}$ \\
\hline 1009 & Seamless & 1400 & 1020 & 880 & 0.7 & $\begin{array}{l}\text { Top cropped, sound \& well } \\
\text { bonded. }\end{array}$ \\
\hline 1010 & Seamless & 1400 & 1020 & 900 & 0.7 & $\begin{array}{l}\text { Top cropped, sound \& well } \\
\text { bonded. }\end{array}$ \\
\hline
\end{tabular}

(a) Cans were all of Zircaloy-2

(b) Can temperature at time of pour. 
Table IV

CASTING DATA FOR CANS OF LARGE DIAMETER

\begin{tabular}{|c|c|c|c|c|c|}
\hline \multirow{2}{*}{$\begin{array}{l}\text { Casting } \\
\text { No. }\end{array}$} & \multirow{2}{*}{$\begin{array}{l}\text { Pouring } \\
\text { Temp, } \\
{ }^{\circ} \mathrm{C}\end{array}$} & \multicolumn{2}{|c|}{ Can Temp } & \multirow{2}{*}{$\begin{array}{l}\text { Vacuum at } \\
\text { Pour, } \\
\text { microns }\end{array}$} & \multirow{2}{*}{ Remarks } \\
\hline & & $\begin{array}{c}\text { Top, } \\
{ }^{\circ} \mathrm{C}\end{array}$ & $\begin{array}{c}\text { Bottom, } \\
{ }^{\circ} \mathrm{C}\end{array}$ & & \\
\hline 1036 & 1345 & 1290 & 1101 & 27 & $\begin{array}{l}\text { Porosity at interface } \\
\text { but bonded. }\end{array}$ \\
\hline 1037 & 1330 & 1330 & 1170 & 12 & $\begin{array}{l}\text { Porosity at interface } \\
\text { but bonded. }\end{array}$ \\
\hline 1038 & -- & -- & -- & -- & $\begin{array}{l}\text { Stopper rod leaked, } \\
\text { no casting. }\end{array}$ \\
\hline 1039 & 1365 & 1365 & 1180 & 17 & $\begin{array}{l}\text { Porosity at interface } \\
\text { but bonded. }\end{array}$ \\
\hline 1040 & 1340 & 1330 & 1025 & 2 & $\begin{array}{l}\text { Severe porosity in core, } \\
\text { poorly bonded. }\end{array}$ \\
\hline 1041 & 1360 & 1360 & 1190 & 35 & $\begin{array}{l}\text { Porosity in core, } \\
\text { fair bond. }\end{array}$ \\
\hline 1042 & 1340 & -- & 1135 & 4 & $\begin{array}{l}\text { Slight porosity in core, } \\
\text { good bond. }\end{array}$ \\
\hline 1043 & 1355 & 1350 & 1170 & 20 & $\begin{array}{l}\text { Slight porosity in core, } \\
\text { unbonded in can weld } \\
\text { area. }\end{array}$ \\
\hline 1044 & 1365 & 1360 & 1240 & 17 & $\begin{array}{l}\text { Porosity in core, } \\
\text { good bond. }\end{array}$ \\
\hline 1075 & 1425 & 1010 & -- & 1 & $\begin{array}{l}\text { Can outgassed at } 1500^{\circ} \mathrm{C} \\
\& 0.02 \text { microns; casting } \\
\text { free of porosity, well } \\
\text { bonded. }\end{array}$ \\
\hline 1076 & 1420 & 995 & -- & 1 & Same as 1075 . \\
\hline 1077 & 1420 & 925 & - & 1 & $\begin{array}{l}\text { Same as } 1075 \text { except for } \\
\text { shrink cavity in core. }\end{array}$ \\
\hline 1078 & 1425 & 1070 & - & 1 & $\begin{array}{l}\text { Same as } 1075 \text { except for } \\
\text { microporosity in upper } \\
\text { end of core. }\end{array}$ \\
\hline
\end{tabular}

Table V.

CASTING DATA FOR SQUARE CORNERED RECTANGU LAR CANS

\begin{tabular}{|c|c|c|c|c|c|}
\hline \multirow{2}{*}{$\begin{array}{l}\text { Casting } \\
\quad \text { No. }\end{array}$} & \multirow{2}{*}{$\begin{array}{l}\text { Pouring } \\
\text { Temp, } \\
{ }^{\circ} \mathrm{C}\end{array}$} & \multicolumn{2}{|c|}{ Can Temp* } & \multirow{2}{*}{$\begin{array}{l}\text { Vacuum at } \\
\text { Pour, } \\
\text { microns }\end{array}$} & \multirow[b]{2}{*}{ Remarks } \\
\hline & & $\begin{array}{l}\text { Top, } \\
{ }^{\circ} \mathrm{C}\end{array}$ & $\begin{array}{l}\text { Bottom, } \\
{ }^{\circ} \mathrm{C}\end{array}$ & & \\
\hline 1011 & 1560 & 661 & 358 & 2 & Completely unbonded. \\
\hline 1012 & 1410 & 1070 & 840 & 1 & Can bulged, unbonded at corners. \\
\hline 1013 & 1415 & & 1015 & 1 & Unbonded at corners. \\
\hline 1017 & 1410 & 1100 & 1050 & 1 & $\begin{array}{l}\text { Poorly bonded at top, porous } \\
\text { interface. }\end{array}$ \\
\hline 1018 & 1470 & 1070 & 1070 & 9 & Can reused, completely unbonded. \\
\hline
\end{tabular}

* Can temperature at time of pour. 
Table VI

CASTING DATA FOR ROUND-CORNERED RECTANGULAR CANS

\begin{tabular}{|c|c|c|c|c|c|c|c|}
\hline \multirow{2}{*}{$\begin{array}{l}\text { Casting } \\
\text { No. }\end{array}$} & \multirow{2}{*}{$\begin{array}{l}\text { Pour. } \\
\text { Temp, } \\
{ }^{\circ} \mathrm{C}\end{array}$} & \multicolumn{3}{|c|}{ Can Temp * } & \multirow{2}{*}{$\begin{array}{l}\text { Can } \\
\text { Heating } \\
\text { Method }\end{array}$} & \multirow{2}{*}{$\begin{array}{l}\text { Vacuum } \\
\text { at Pour, } \\
\text { microns }\end{array}$} & \multirow{2}{*}{ Remarks } \\
\hline & & $\stackrel{\text { Top, }}{{ }^{\circ} \mathrm{C}}$ & $\begin{array}{l}\text { Center, } \\
{ }^{\circ} \mathrm{C}\end{array}$ & $\begin{array}{l}\text { Bottom, } \\
{ }^{\circ} \mathrm{C}\end{array}$ & & & \\
\hline 1021 & 1440 & 1120 & -- & -- & $\begin{array}{l}\text { Resistance } \\
\text { Elements }\end{array}$ & 6 & Bonded, core shrinkage. \\
\hline 1033 & 1380 & 1260 & -- & 1140 & $\begin{array}{l}\text { Resistance } \\
\text { Elements }\end{array}$ & 4 & $\begin{array}{l}\text { Bonded, core shrinkage } \\
3 \frac{1}{2} " \text { from bottom. }\end{array}$ \\
\hline 1034 & 1370 & 1350 & -- & 1075 & $\begin{array}{l}\text { Resistance } \\
\text { Elements }\end{array}$ & 1 & $\begin{array}{l}\text { Bonded, core shrinkage } \\
5 \frac{1}{4} " \text { from bottom. }\end{array}$ \\
\hline 1038 & 1315 & 1300 & 1250 & 1090 & Induction & 7 & $\begin{array}{l}\text { Bonded, porous interface, } \\
\text { core shrinkage. }\end{array}$ \\
\hline 1040 & 1340 & 1330 & 1180 & 1025 & Induction & 2 & Same as 1038 \\
\hline 1042 & 1340 & -- & 1300 & 1135 & Induction & 4 & Same as 1038 \\
\hline 1045 & 1370 & 1145 & 1115 & 1040 & Globar & 10 & $\begin{array}{l}\text { Unbonded, brittle } \mathrm{Zr}-2 \text {, } \\
\text { core shrinkage. }\end{array}$ \\
\hline 1046 & 1450 & 1170 & 1130 & 1050 & Globar & 500 & Same as 1045 \\
\hline 1047 & 1450 & 1220 & 1210 & 1040 & Globar & 70 & $\begin{array}{l}\text { Bonded, brittle } \mathrm{Zr}-2 \text {, } \\
\text { shrinkage } 5 \frac{1}{2} " \text { from } \\
\text { bottom. }\end{array}$ \\
\hline 1048 & 1405 & 1150 & 1090 & 1050 & Globar & 35 & Same as 1047 \\
\hline 1049 & 1405 & 1160 & 1070 & 1010 & Globar & 100 & $\begin{array}{l}\text { Bonded, brittle } \mathrm{Zr}-2 \text {, } \\
\text { shrinkage } 5^{\prime \prime} \text { from } \\
\text { bottom. }\end{array}$ \\
\hline 1050 & 1445 & 1160 & 1095 & 995 & Globar & 17 & $\begin{array}{l}\text { Bonded, ductile } \mathrm{Zr}-2 \text {, } \\
\text { shrinkage } 5 \text { " from } \\
\text { bottom. }\end{array}$ \\
\hline 1051 & 1420 & 1075 & 850 & 890 & Globar & 1 & $\begin{array}{l}\text { Bonded, ductile } \mathrm{Zr}-2 \text {, } \\
\text { shrinkage } 6 \frac{1}{2} " \text { from } \\
\text { bottom. }\end{array}$ \\
\hline 1052 & 1450 & 1100 & 910 & 915 & Globar & 0.9 & $\begin{array}{l}\text { Bonded, ductile } \mathrm{Zr}-2 \text {, } \\
\text { shrinkage } 5 \text { "from } \\
\text { bottom. }\end{array}$ \\
\hline 1053 & 1435 & 1105 & 980 & 930 & Globar & 0.8 & $\begin{array}{l}\text { Bonded, ductile } \mathrm{Zr}-2 \text {, } \\
\text { shrinkage } 5 \frac{3}{4} \text { from } \\
\text { bottom. }\end{array}$ \\
\hline 1054 & 1415 & - & -- & -- & Globar & 0.7 & Same as 1052 \\
\hline
\end{tabular}

*Can temperature at time of pour. 
Table VII ANALYSES OF ZIRCALOY - 2 CANS EMBRITTLED
DURING MELT CYCLE

\begin{tabular}{|c|c|c|c|}
\hline $\begin{array}{c}\text { Casting } \\
\text { No. }\end{array}$ & $\begin{array}{c}\mathrm{C} \\
(\mathrm{ppm})\end{array}$ & $\begin{array}{c}\mathrm{O} \\
(\mathrm{w} / \mathrm{o})\end{array}$ & $\begin{array}{c}\mathrm{N} \\
(\mathrm{ppm})\end{array}$ \\
\hline 1045 & 74 & $0.78-0.92$ & 69 \\
1046 & 75 & 0.84 & 45 \\
\hline
\end{tabular}

Table VIII

CASTING DATA FOR SIDE STRIP CASTINGS

\begin{tabular}{|c|c|c|c|c|c|c|}
\hline $\begin{array}{l}\text { Casting } \\
\text { No. }\end{array}$ & $\begin{array}{c}\text { Type } \\
\text { of } \\
\text { Mold(a) }\end{array}$ & $\begin{array}{l}\text { Mold Cross Section } \\
\text { and Length, in. }\end{array}$ & $\begin{array}{c}\text { Thickness } \\
\text { of Zr-2 } \\
\text { Strips, } \\
\text { in. }\end{array}$ & $\begin{array}{l}\text { Pour } \\
\text { Temp, } \\
{ }^{\circ} \mathrm{C}\end{array}$ & $\begin{array}{c}\text { Vacuum at } \\
\text { Pour, } \\
\text { microns }\end{array}$ & Remarks \\
\hline $1-86$ & I & $2 \frac{3}{2} \times 2 \frac{3}{4} \times 9 \frac{1}{2}$ & $1 / 8$ & 1420 & I & $\begin{array}{l}\text { Clad separated from core at core edges. } \\
\text { Some porosity in core. }\end{array}$ \\
\hline$L-128$ & II & $1 \frac{3}{16} \times 2 \frac{1}{4} \times 9 \frac{3}{4}$ & $1 / 8$ & 1470 & 40 & $\begin{array}{l}\text { Ingot sound at sample locations. Surface } \\
\text { good. No blowholes on machined surface }\end{array}$ \\
\hline L- 129 & II & $1 \frac{3}{8} \times 2 \frac{1}{2} \times 8 \frac{3}{4}$ & $1 / 8$ & 1500 & 100 & $\begin{array}{l}\text { Numerous blowholes at core-clad inter- } \\
\text { face after machining. }\end{array}$ \\
\hline$L-130$ & II & $1 \frac{3}{16} \times 2 \frac{1}{4} \times 9 \frac{3}{4}$ & $1 / 8$ & 1495 & 45 & Sound after machining of core. \\
\hline L-131 & II & $1 \frac{3}{8} \times 2 \frac{1}{2} \times 8 \frac{3}{4}$ & $1 / 8$ & 1490 & 100 & $\begin{array}{l}\text { Several blowholes at core-clad interface } \\
\text { on one side only after machining. }\end{array}$ \\
\hline L- 132 & II & $1 \frac{3}{16} \times 2 \frac{1}{4} \times 9 \frac{3}{4}$ & $1 / 8$ & 1500 & 25 & $\begin{array}{l}\text { Few blowholes at core-clad interface } \\
\text { after machining. }\end{array}$ \\
\hline L-134 & II & $1 \frac{3}{8} \times 2 \frac{1}{2} \times 8 \frac{3}{4}$ & $1 / 8$ & 1485 & 150 & $\begin{array}{l}\text { Numerous small blowholes at core-clad } \\
\text { interface after machining. }\end{array}$ \\
\hline L-139 & II & $1 \times 2 \frac{3}{8} \times 9$ & $1 / 8$ & 1530 & 25 & $\begin{array}{l}\text { Large blowholes at core-clad interface } \\
\text { after machining. }\end{array}$ \\
\hline L- 140 & II & $1 \times 2 \frac{3}{8} \times 9$ & $1 / 8$ & 1530 & 80 & $\begin{array}{l}\text { Mold insulated with } \mathrm{ZrO}_{2} \text { tube, casting } \\
\text { sound. }\end{array}$ \\
\hline L- 141 & II & $1 \times 2 \frac{3}{8} \times 9$ & $1 / 8$ & 1525 & 22 & Same as $L-140$ \\
\hline L- 148 & II & $1 \frac{1}{4} \times 2 \frac{1}{8} \times 8 \frac{1}{2}$ & $1 / 4$ & $\cdot 1505$ & 13 & Same as $L-140$. \\
\hline L- 149 & II & $1 \frac{1}{4} \times 2 \frac{1}{8} \times 8 \frac{1}{2}$ & $1 / 4$ & 1510 & 15 & Same as $L-140$ \\
\hline
\end{tabular}

(a) See Figure 23 for sketches of mold types. 
FIGURE 1. Sketch of Crucible, Heater, Can, and Can Fixture Arrangement for Pin Castings.

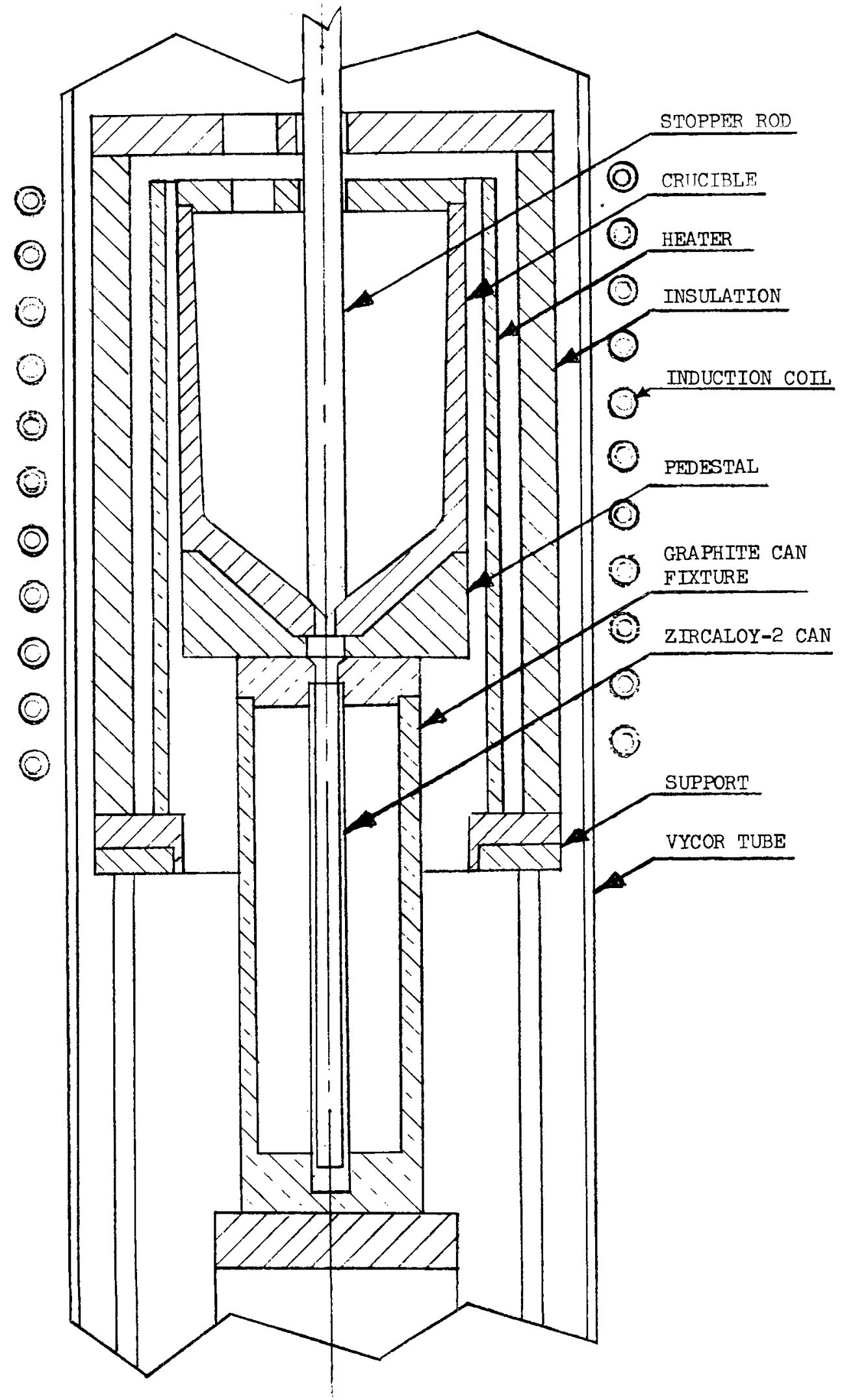


FIGURE 2. Graphite Fixture for Support and Heating Zircaloy-2 Cans for Pin Castings.
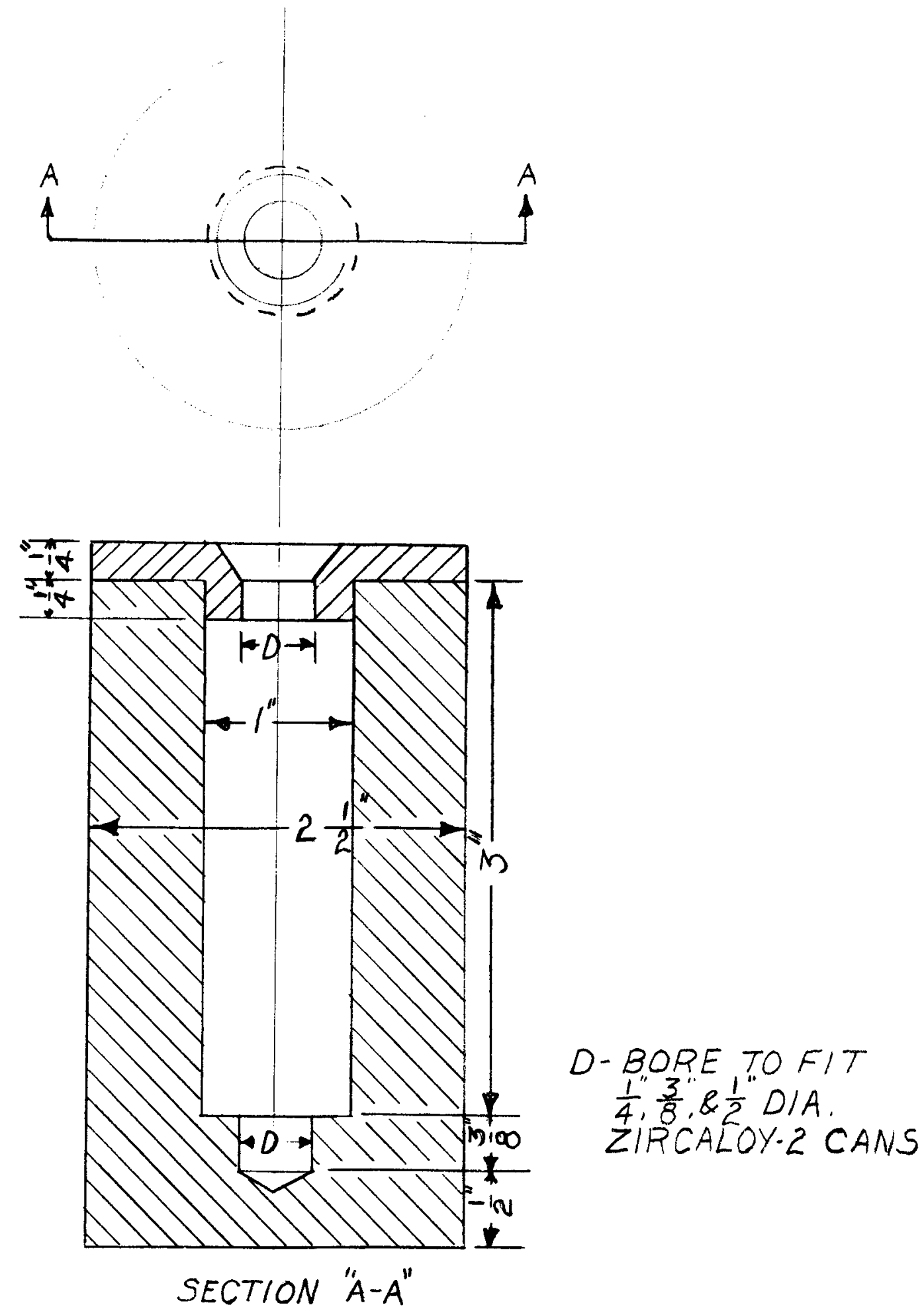
FIGURE 3. Photographs of Pin Castings with Top $1 / 2$ " Removed by Cutting. Castings, Left to Right, 1032, 1/4" dia., 1026 and 1030, 3/8" dia., and 1025, 1/2" dia.

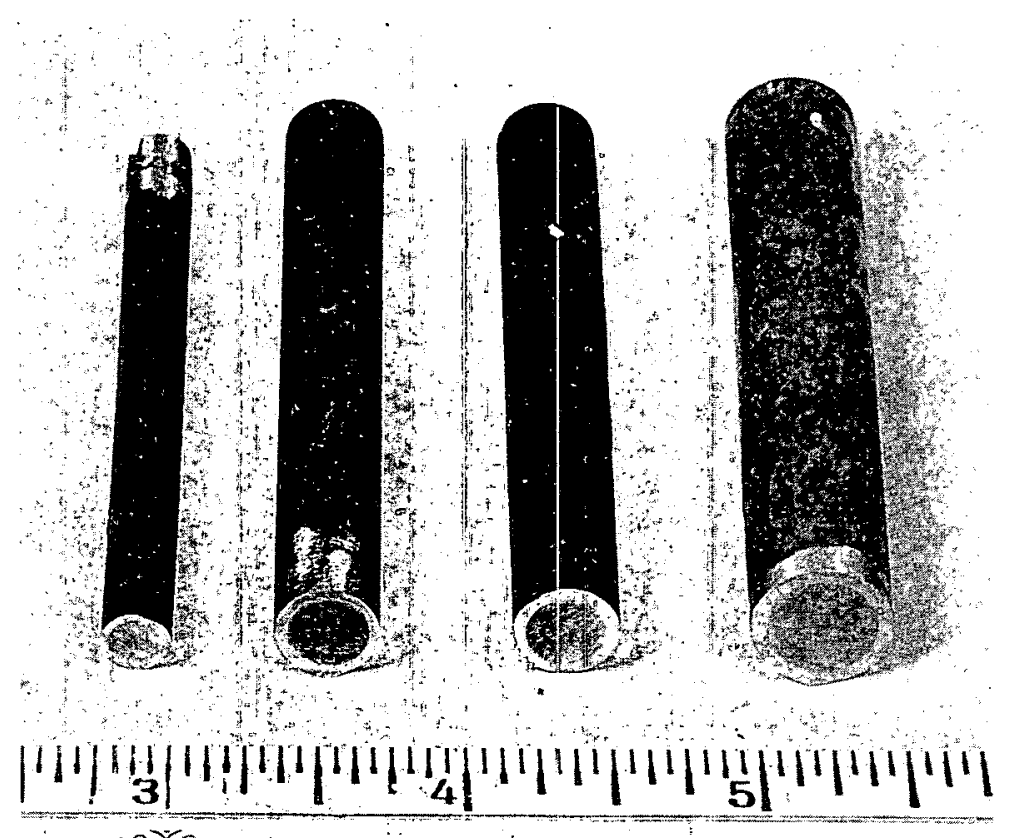

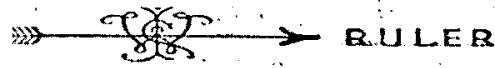

$106-1500$

FIGURE 4. Photomicrograph of Zircaloy-2 Uranium

Core Interface of Casting 1027, As Cast.

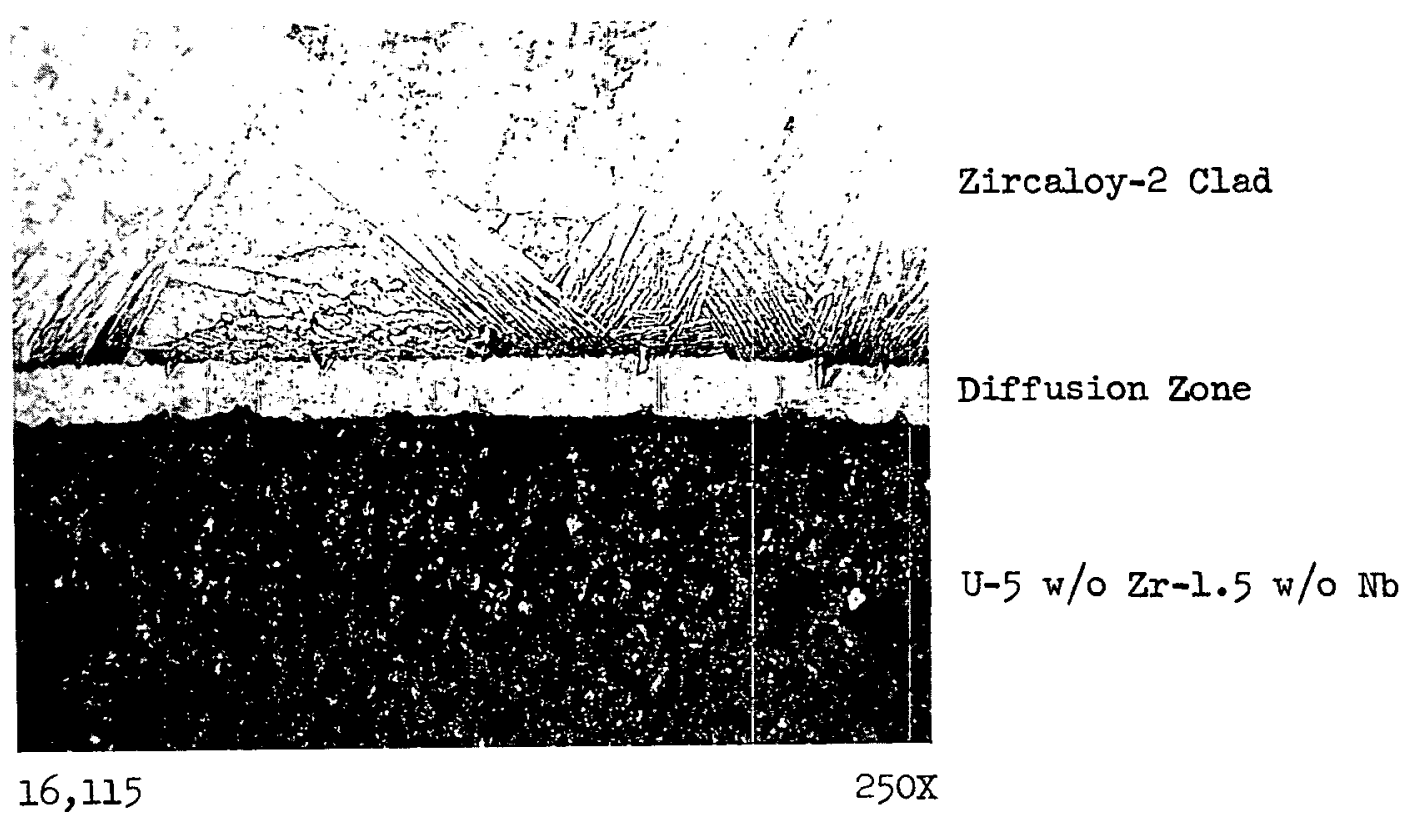


FIGURE 5. Graphite Fixture for Support and Heating of Zircaloy-2 Cans for 1-1/4" Dia. Castings.

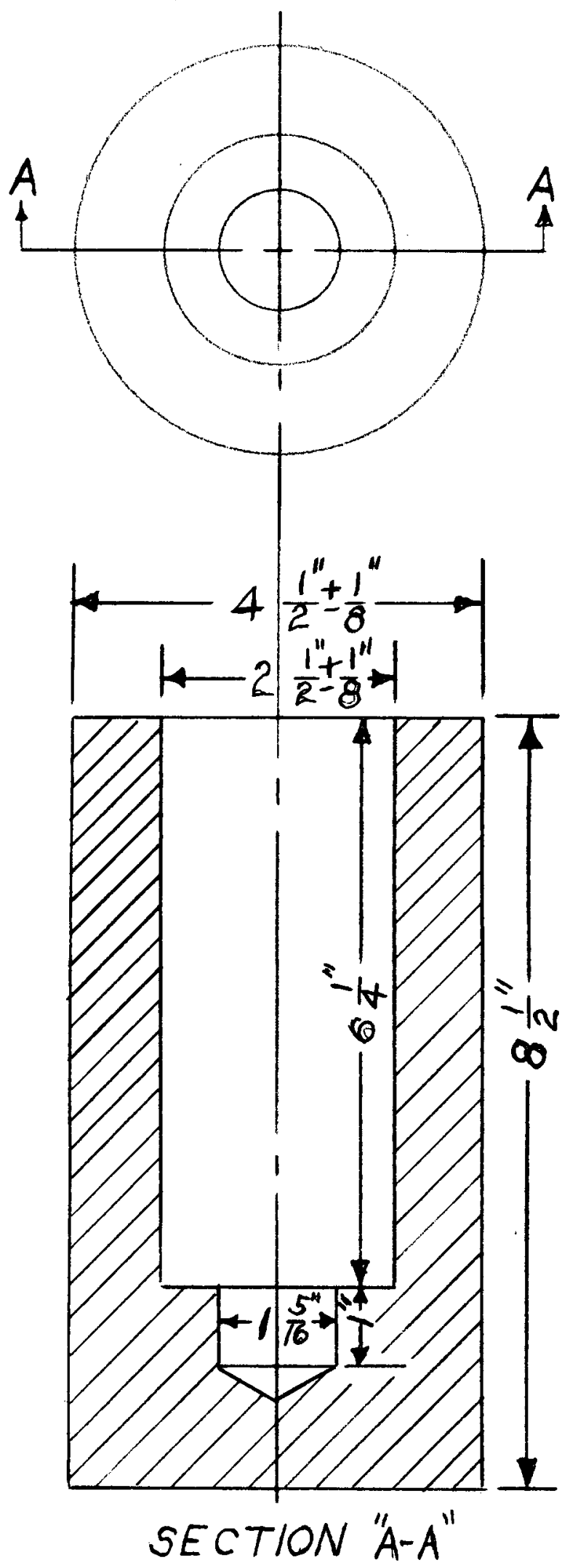


FIGURE 6. Top View and Four Transverse Sections of Casting 1001 Showing Unbond in Can Weld Areas and Inter Porosity.

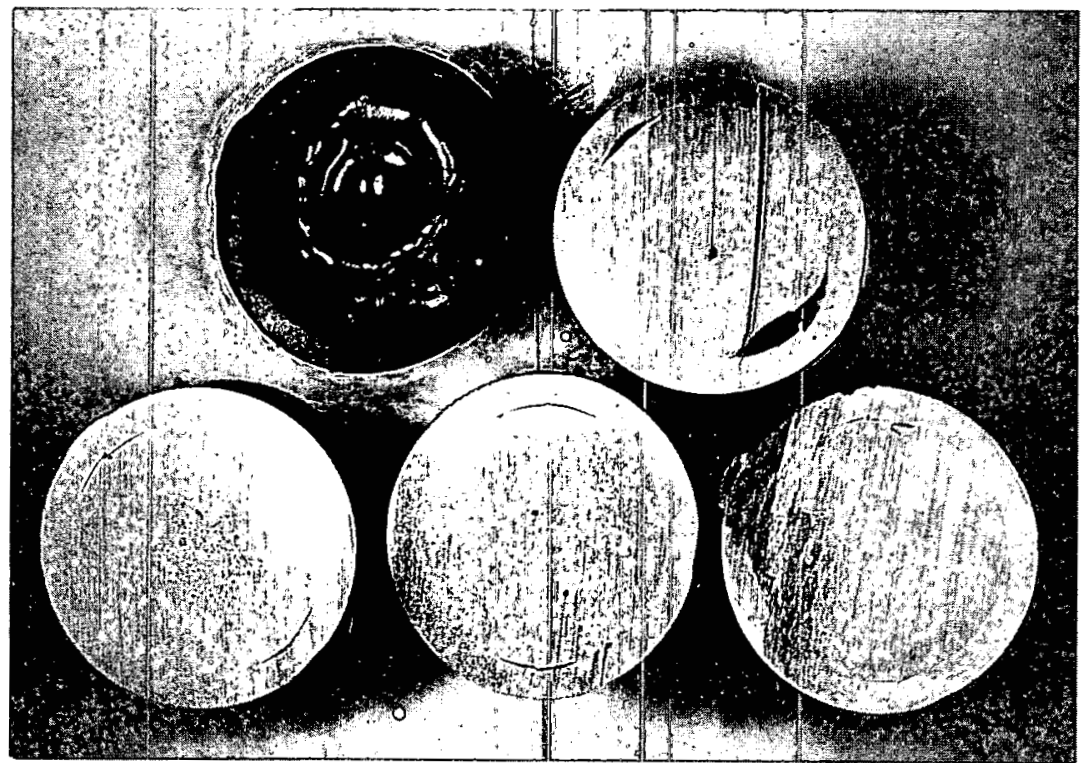

15,474

IX

FIGURE 7. Casting 1007 Sectioned Just below Core Level.

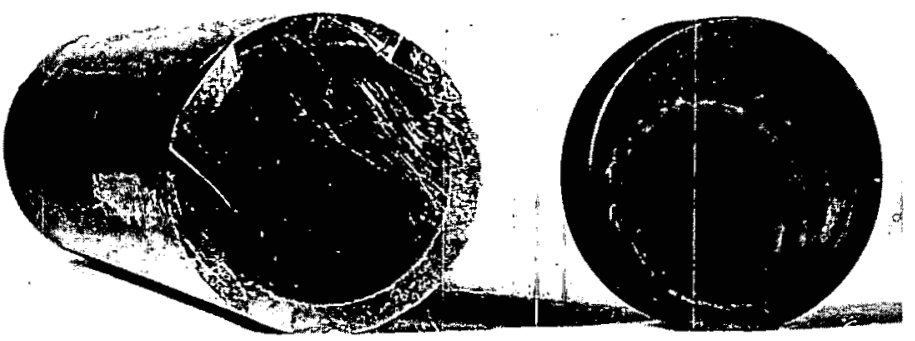

15,588 
FIGURE 8. Zircaloy-2 Uranium Alloy Diffusion Bond of Casting 1005 As Cast and Rolled and Heat Treated.

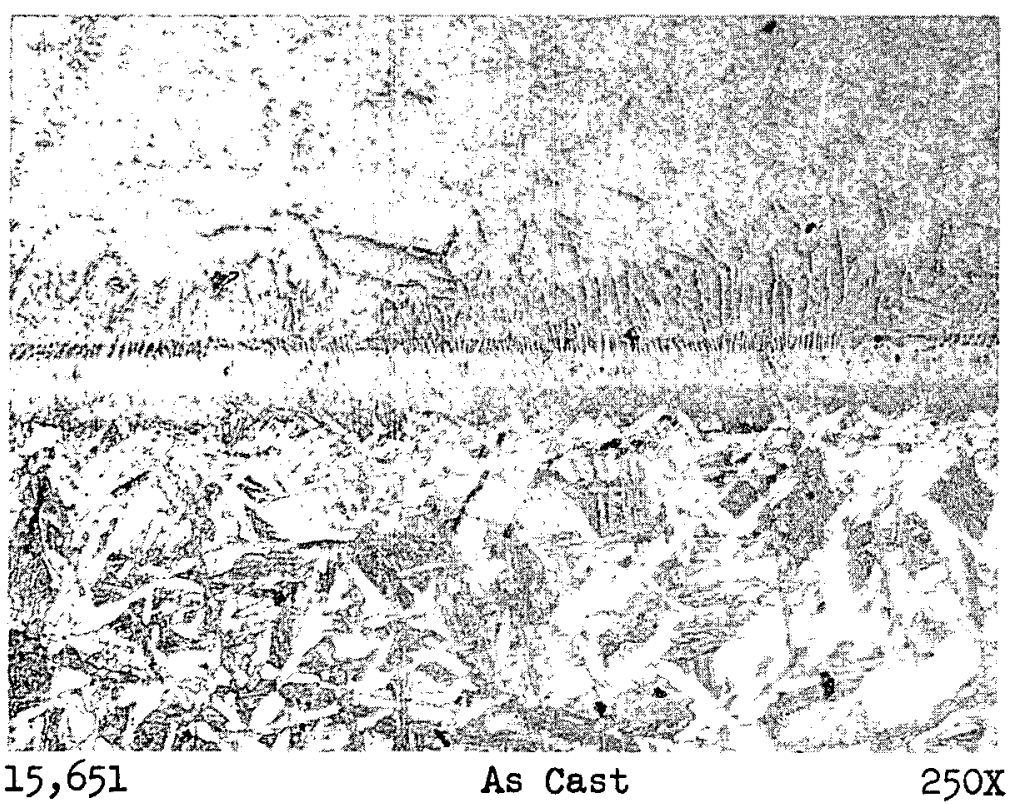

\section{Zircaloy-2}

Diffusion Zone

$\mathrm{U}-5 \mathrm{w} / 0 \mathrm{Zr}-1.5 \mathrm{w} / 0 \mathrm{Nb}$

Zircaloy-2

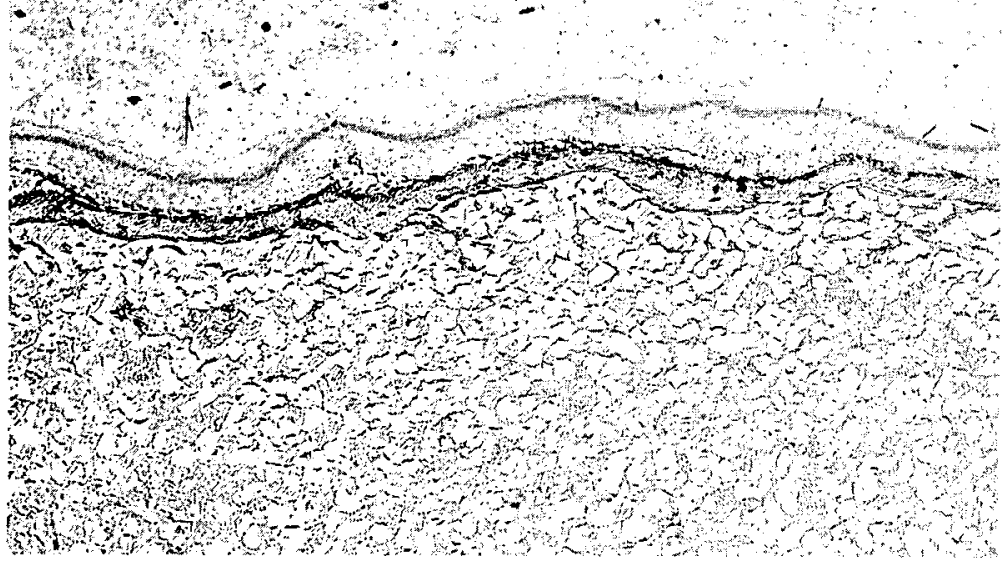

15,652 Rolled to $0.318^{\prime \prime}$ Dia. at $250 x$

Diffusion Zone

$\mathrm{U}-5 \mathrm{w} / 0 \mathrm{Zr}-1.5 \mathrm{w} / 0 \mathrm{Nb}$ $850^{\circ} \mathrm{C}$ and water quenched. 
FIGURE 9. Unbond between Uranium Core and Zirconium Side Plate in a Rolled Fuel Plate.

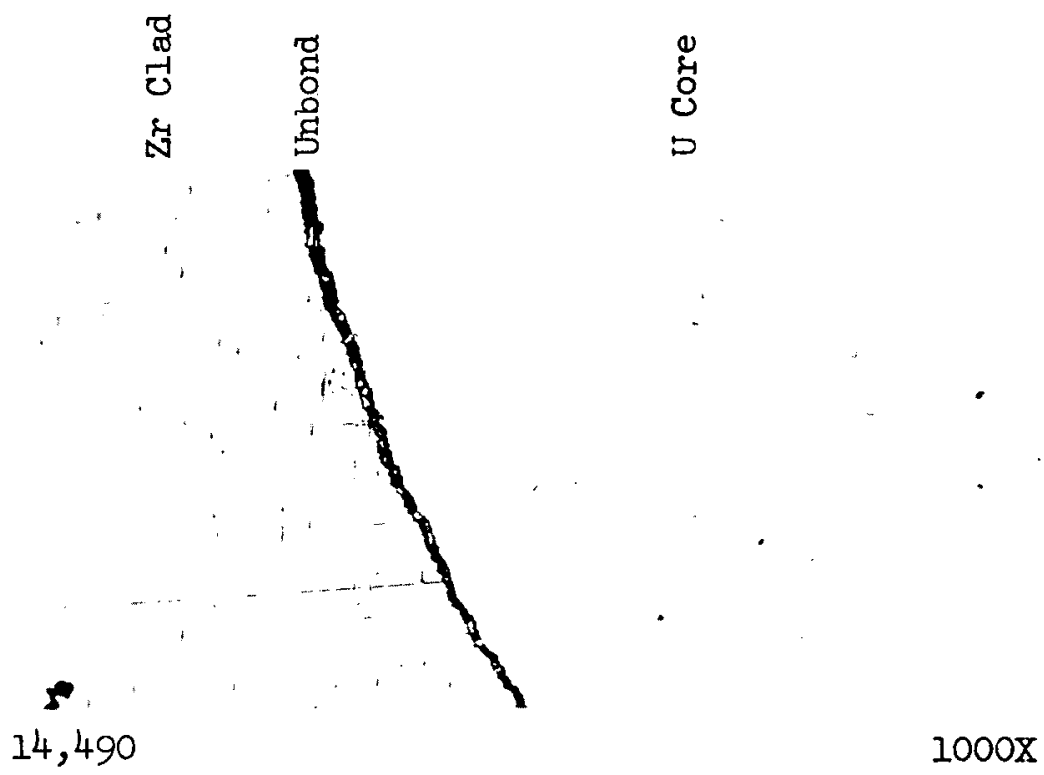

FIGURE 10. Casting 1044 Sectioned to Show Concentration of Blowholes at Core-Clad Interface.
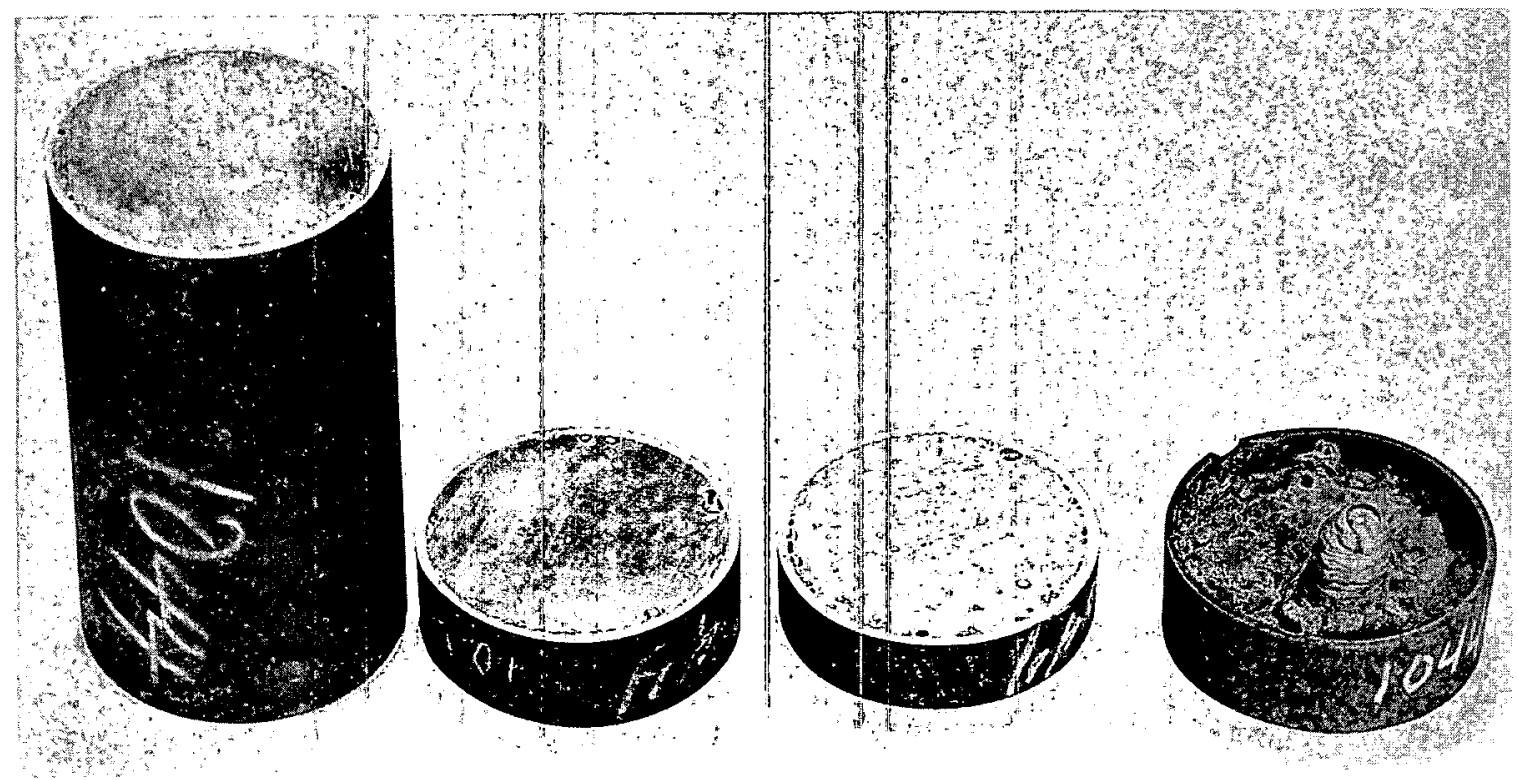

$106-1527$ 


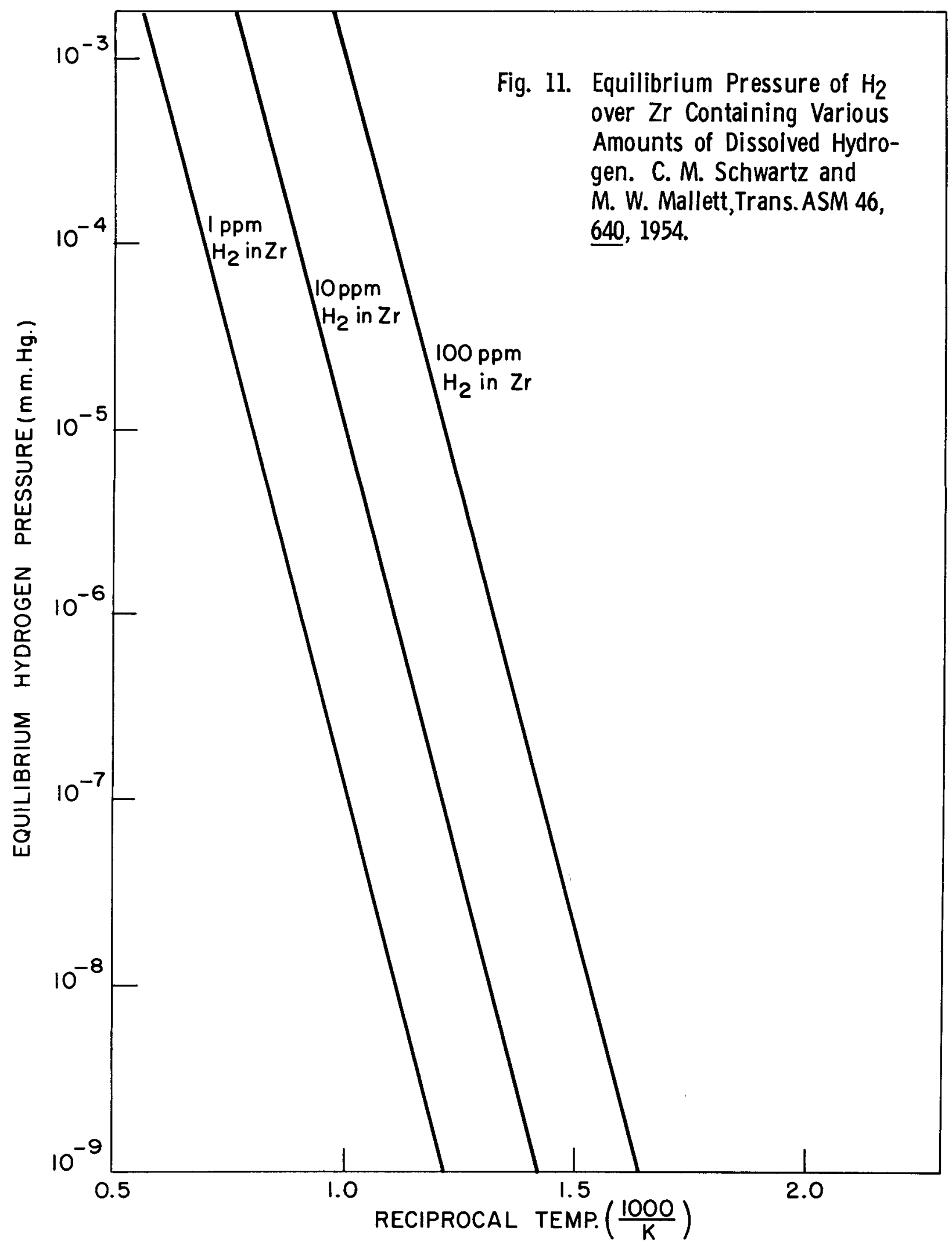



FIGURE 13. Photomicrograph of Cast Bond between Zircaloy-2 and Uranium Alloy Core of Casting 1075 Showing Absence of Porosity.

$$
\text { Zircaloy-2 }
$$

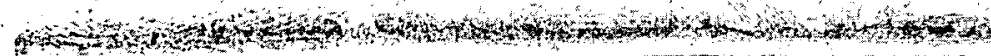

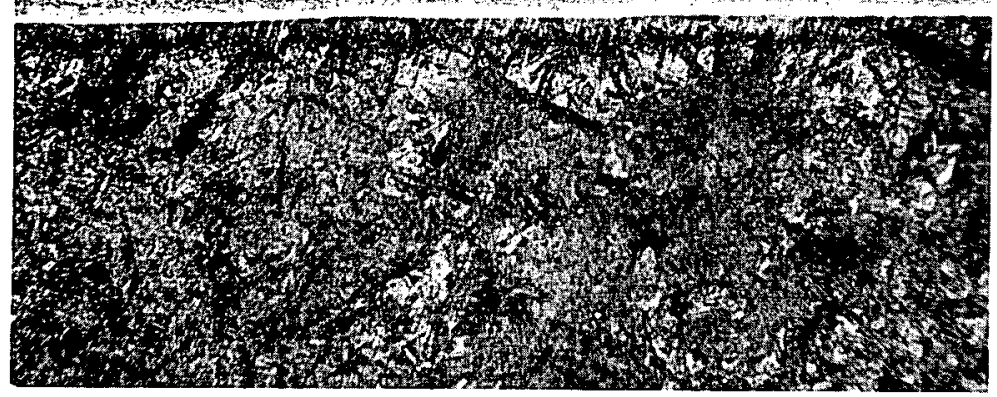

Bond Line

17,519

$250 x$

FIGURE 14. Welded Rectangular Zircaloy-2 Can with Sharp Corners.

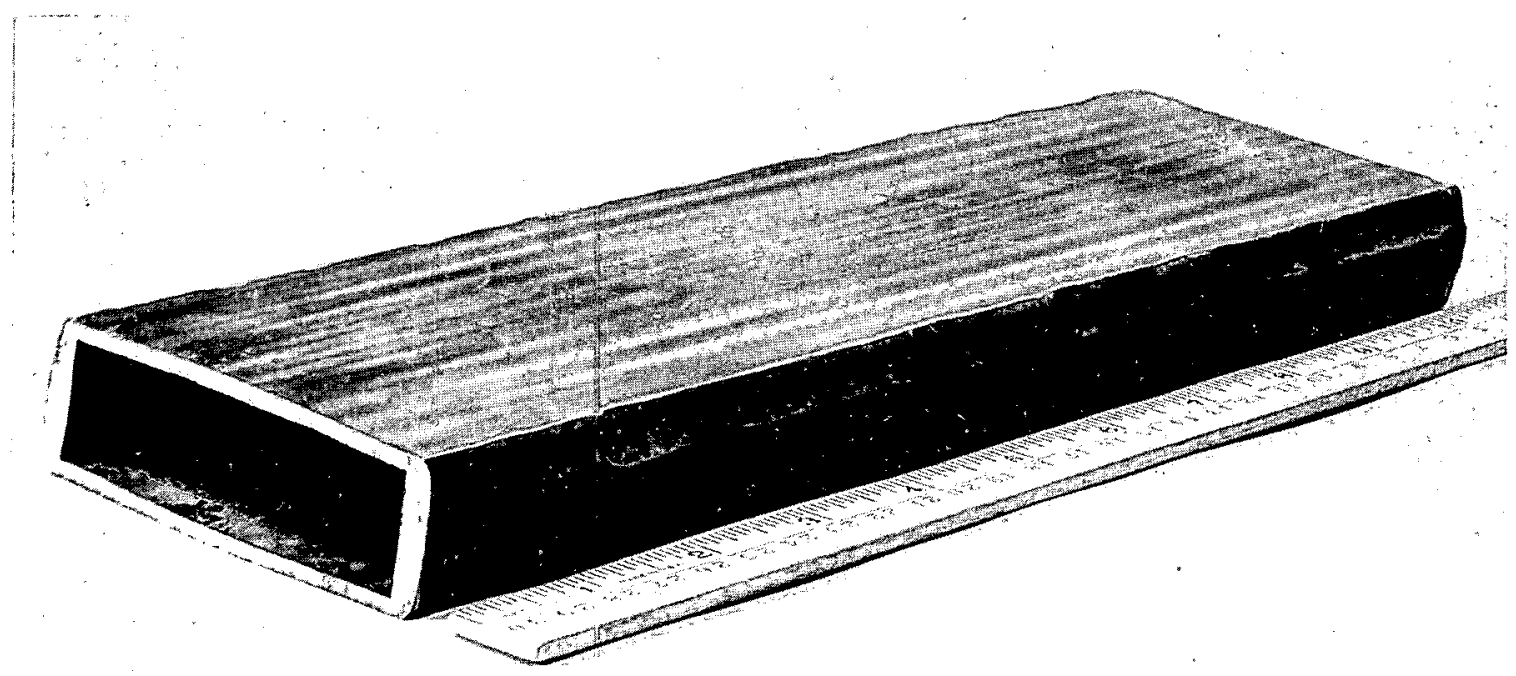

$106-1431$ 


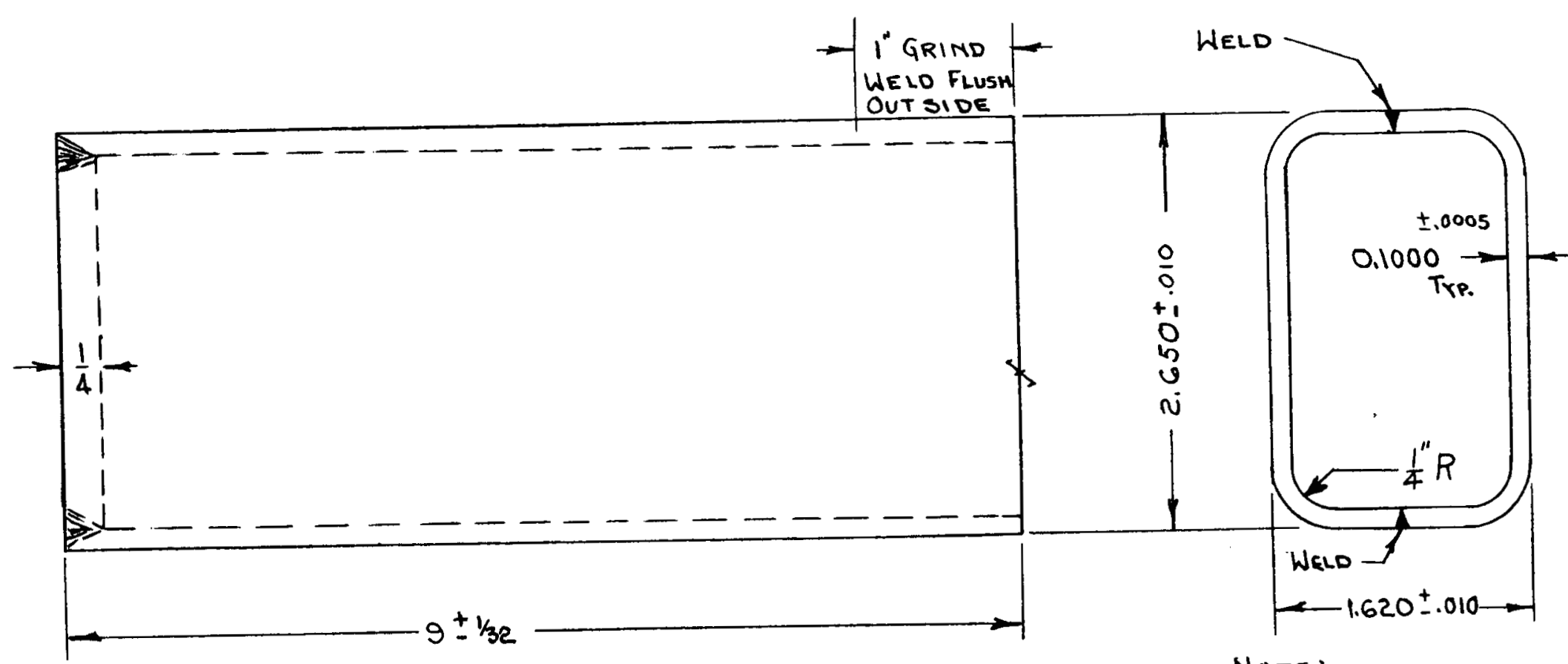

NOTE:

Zircalor Can made from halves

BY WELDING. IN AN INERT ATMOSPHERE
TOP MACHINED AFTER WELDING

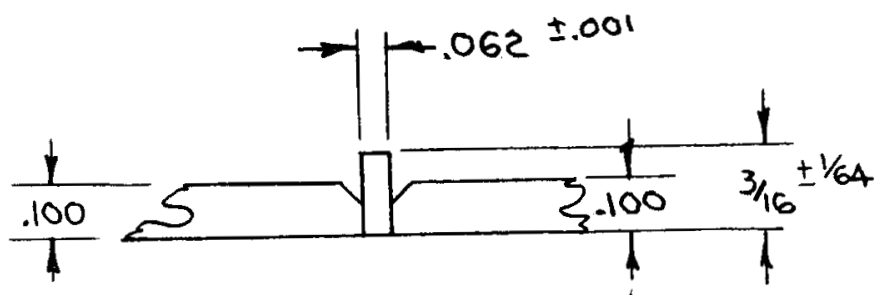

METHOD OF WELDING SIDES
FIGURE 15

zircalor Can of Rectangulalar Cross SECTION WITH CORNER Rad (TYPE 111)

$\stackrel{w}{\omega}$ 
FIGURE 16. Hot Formed Zircaloy-2 Channels Used in Fabricating Welded Can.



$106-1471$

1 
FIGURE 17. Globar Furnace Used f'or Heating Rectangular

Cross-Sectional Cans with Corner Radii.

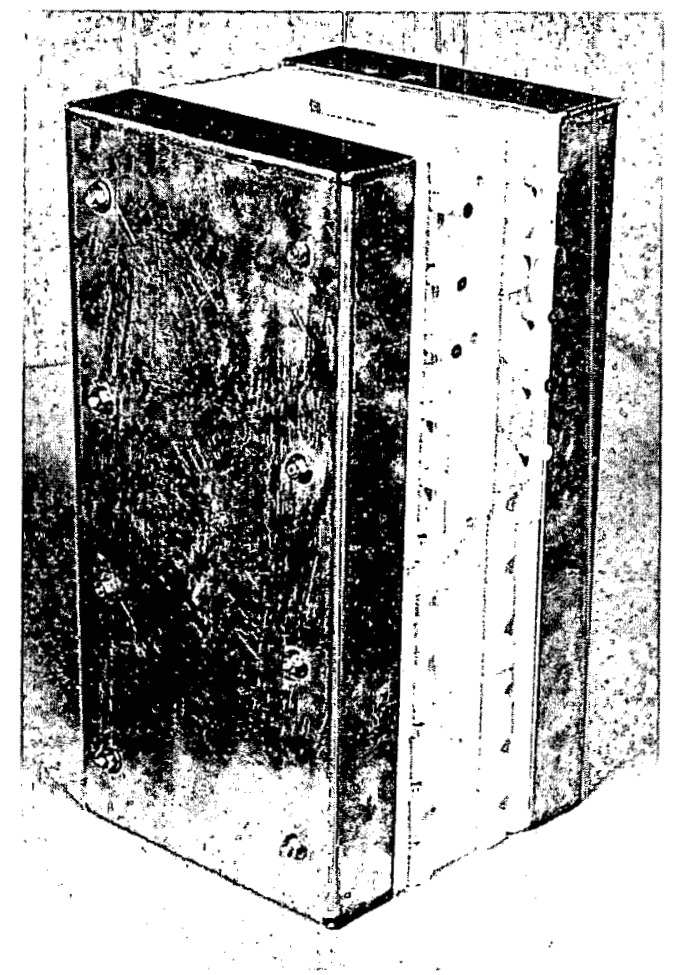

$106-1501$

FIGURE 18. Photomicrograph of Cast Bond in Casting 1021.

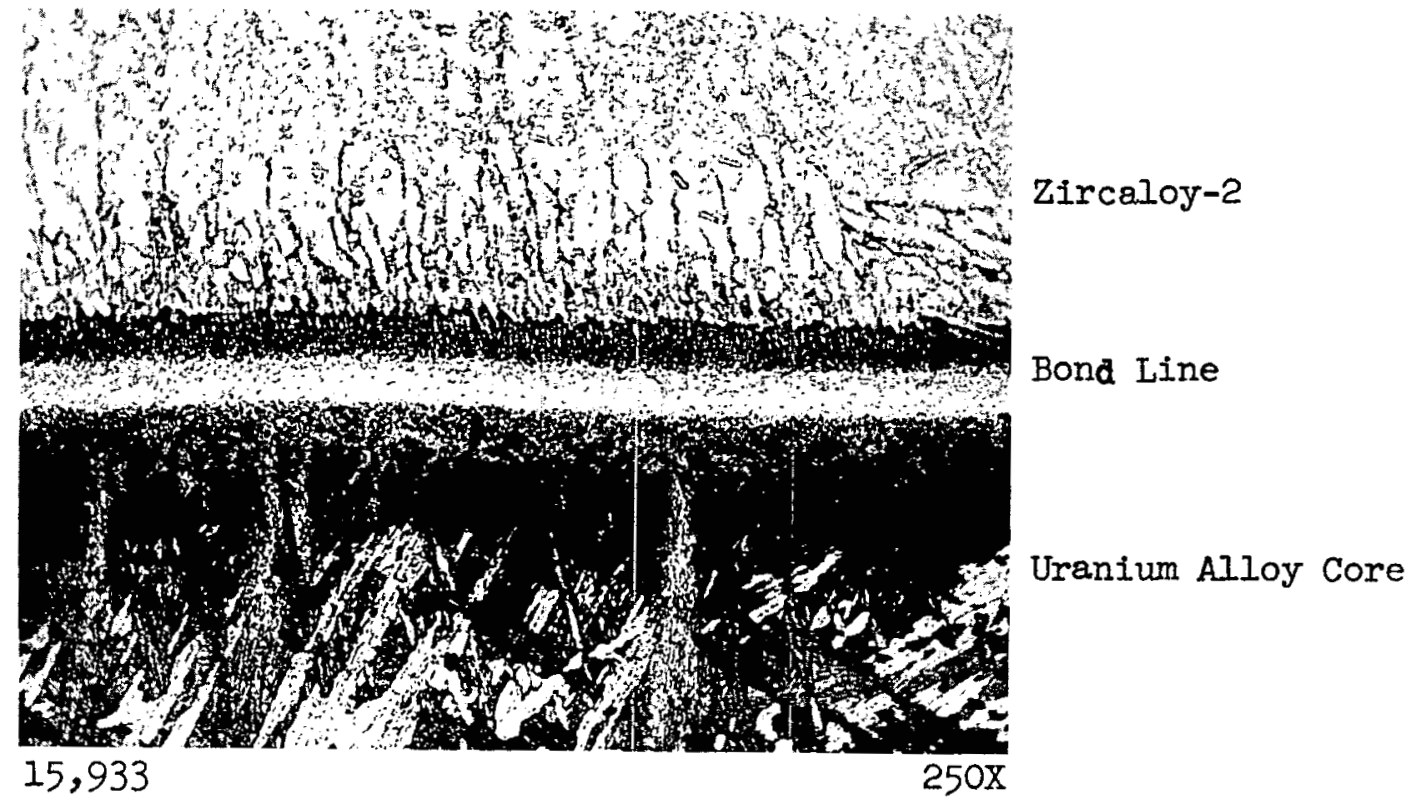


FIGURE 19. Casting 1034 Sectioned Showing Core Porosity in Center of Casting.

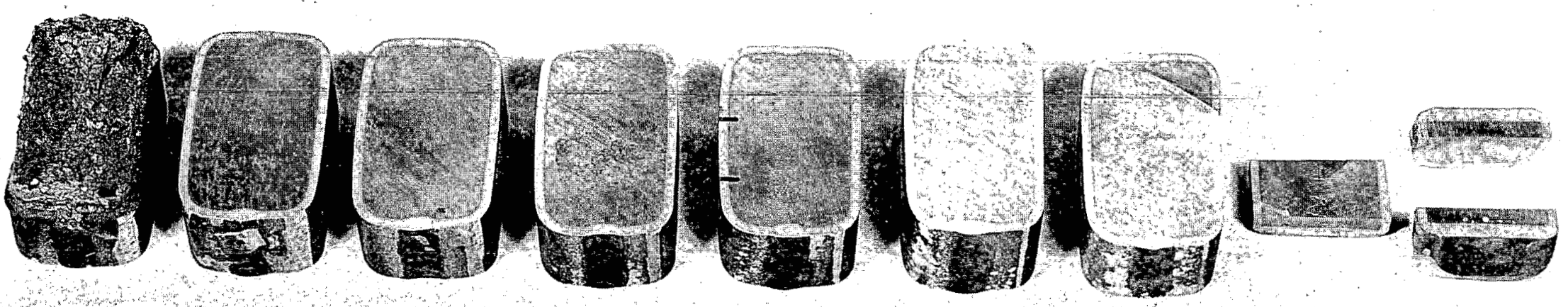

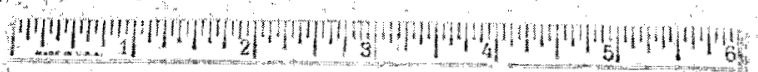

$106-1503$ 


\section{1}

FIGURE 20. Casting 1040 Sectioned to Show Concentration of Interfacial Porosity at Top of Casting.

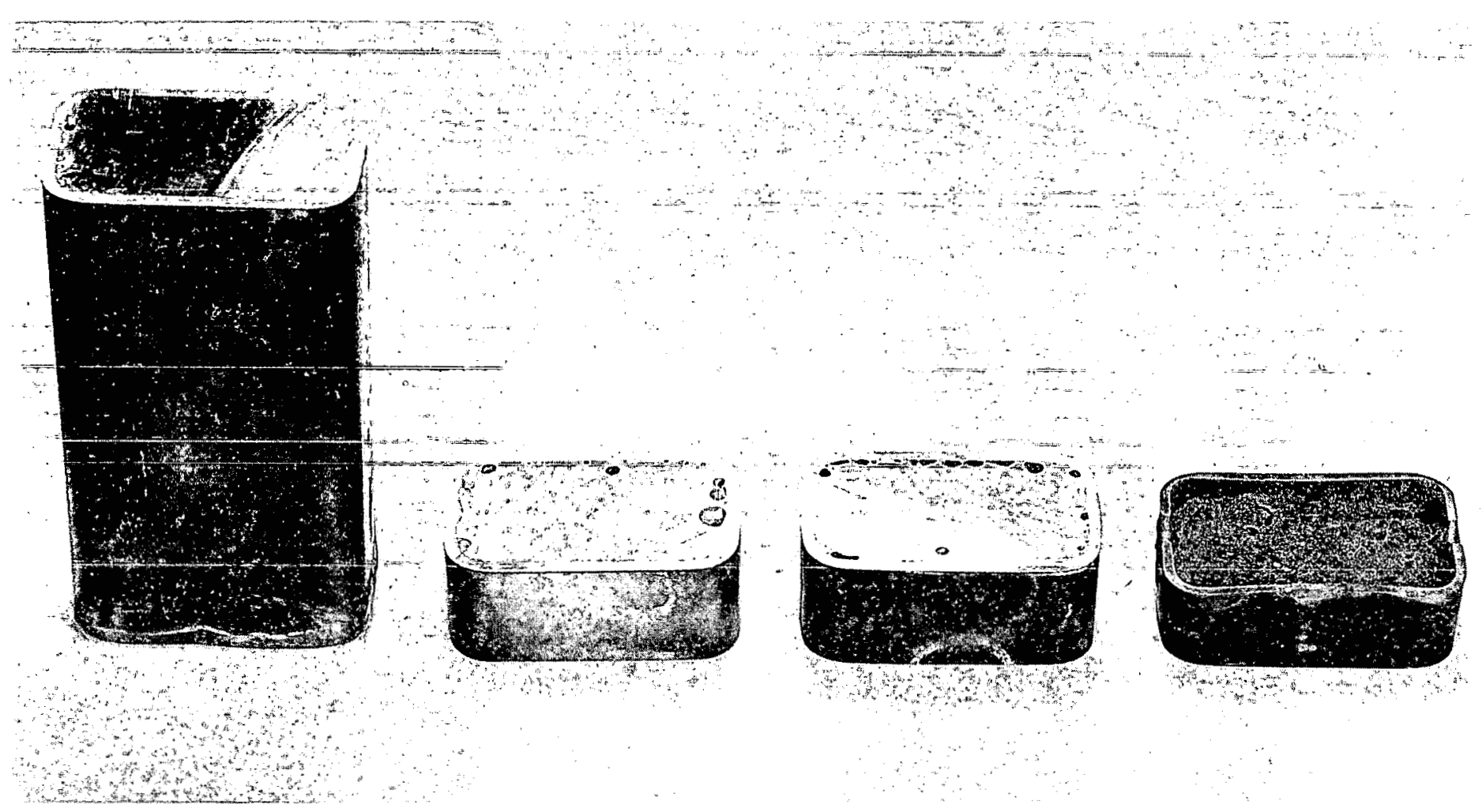

$106-1526$ 
FIGURE 21. Casting 1049 Sectioned to Show Lack of Bond Toward Top of Casting Resulting from Embrittled Zircaloy-2.

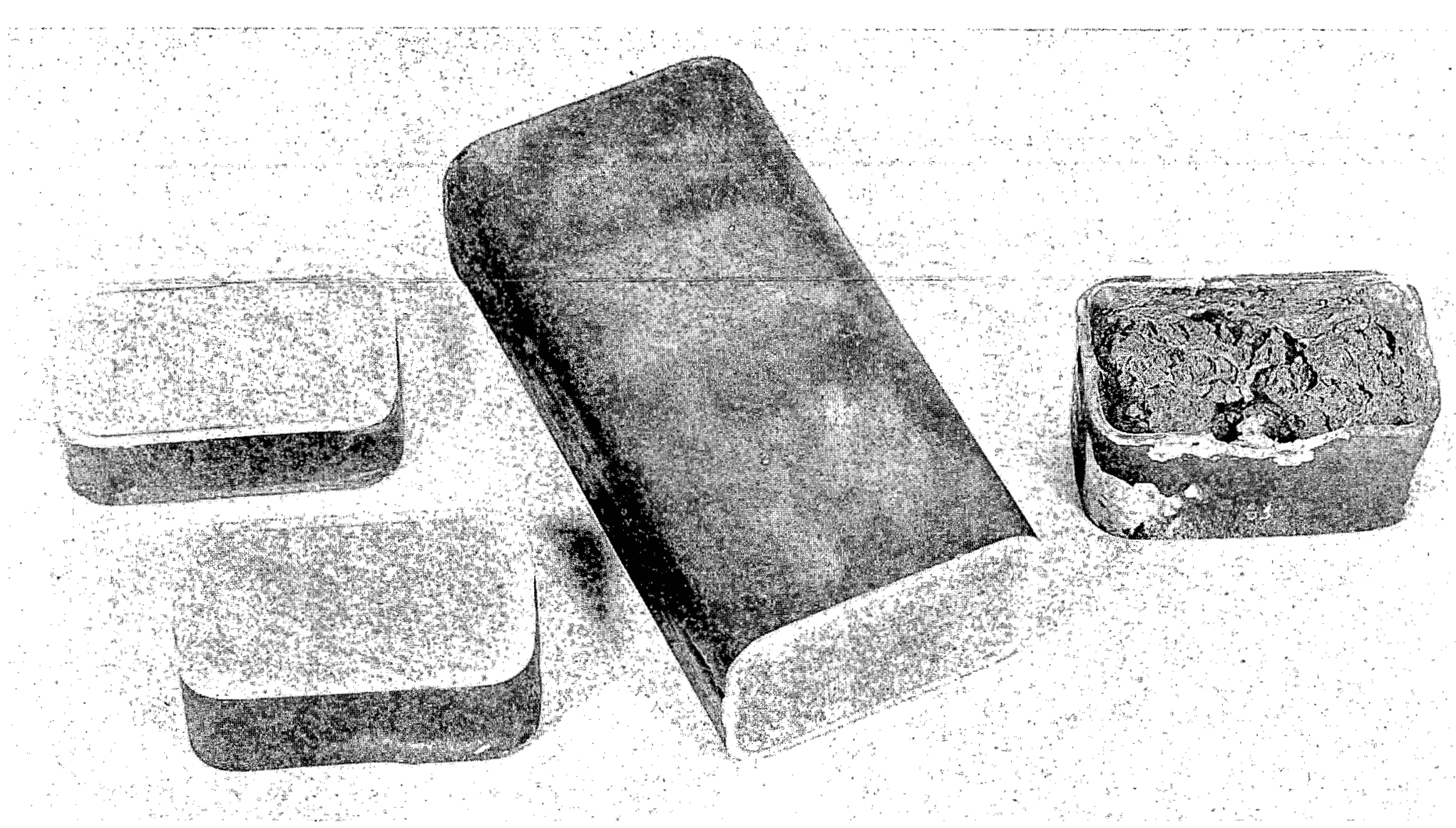

106-1587 
FIGURE 22. Cutaway Sketches of the Two Types of Molds Used for Side Strip Castings.

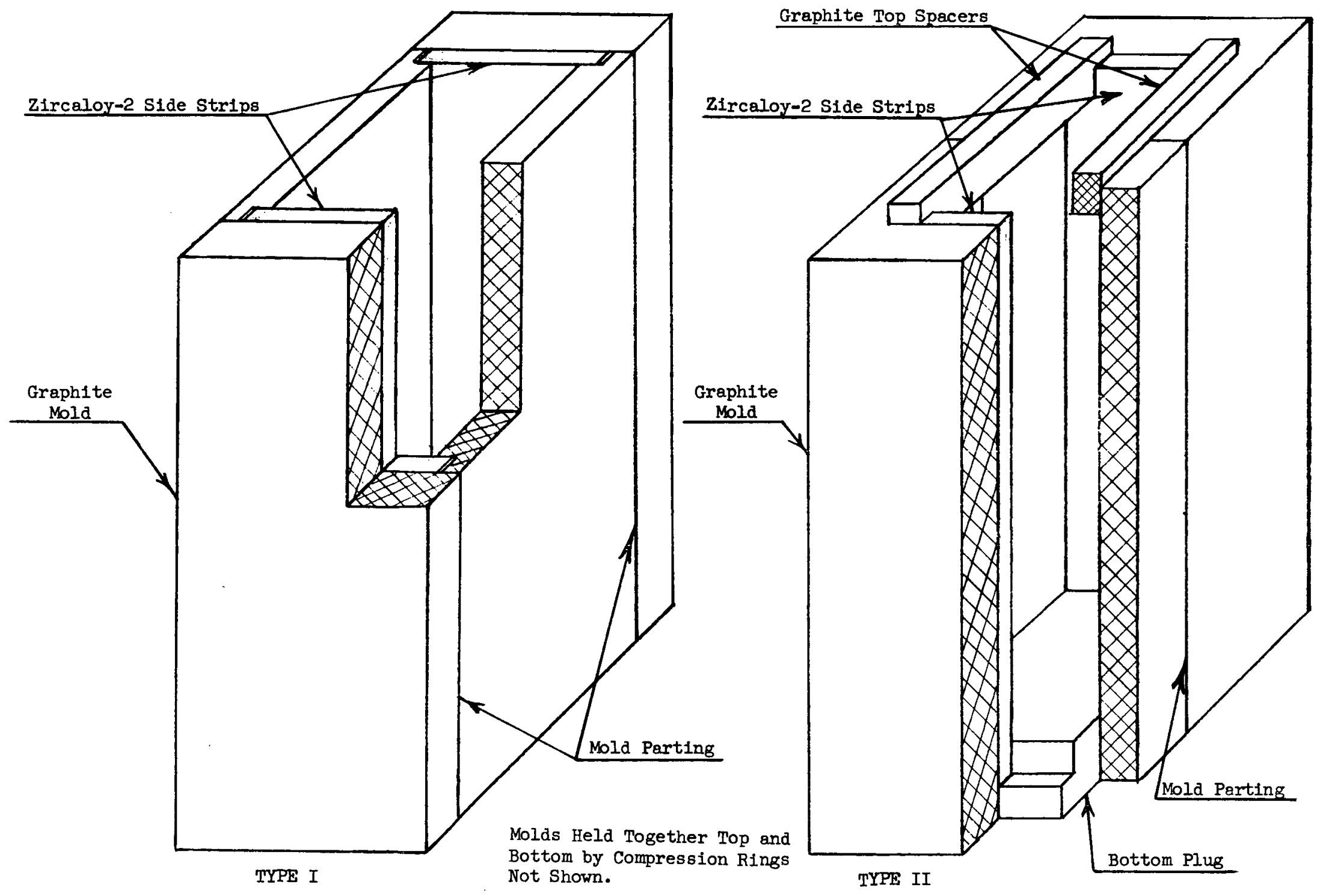




\section{FIGURE 23. Side Strip Casting Showing Uranium Alloy Cast Bonded to Zircaloy-2 Side Strips.}

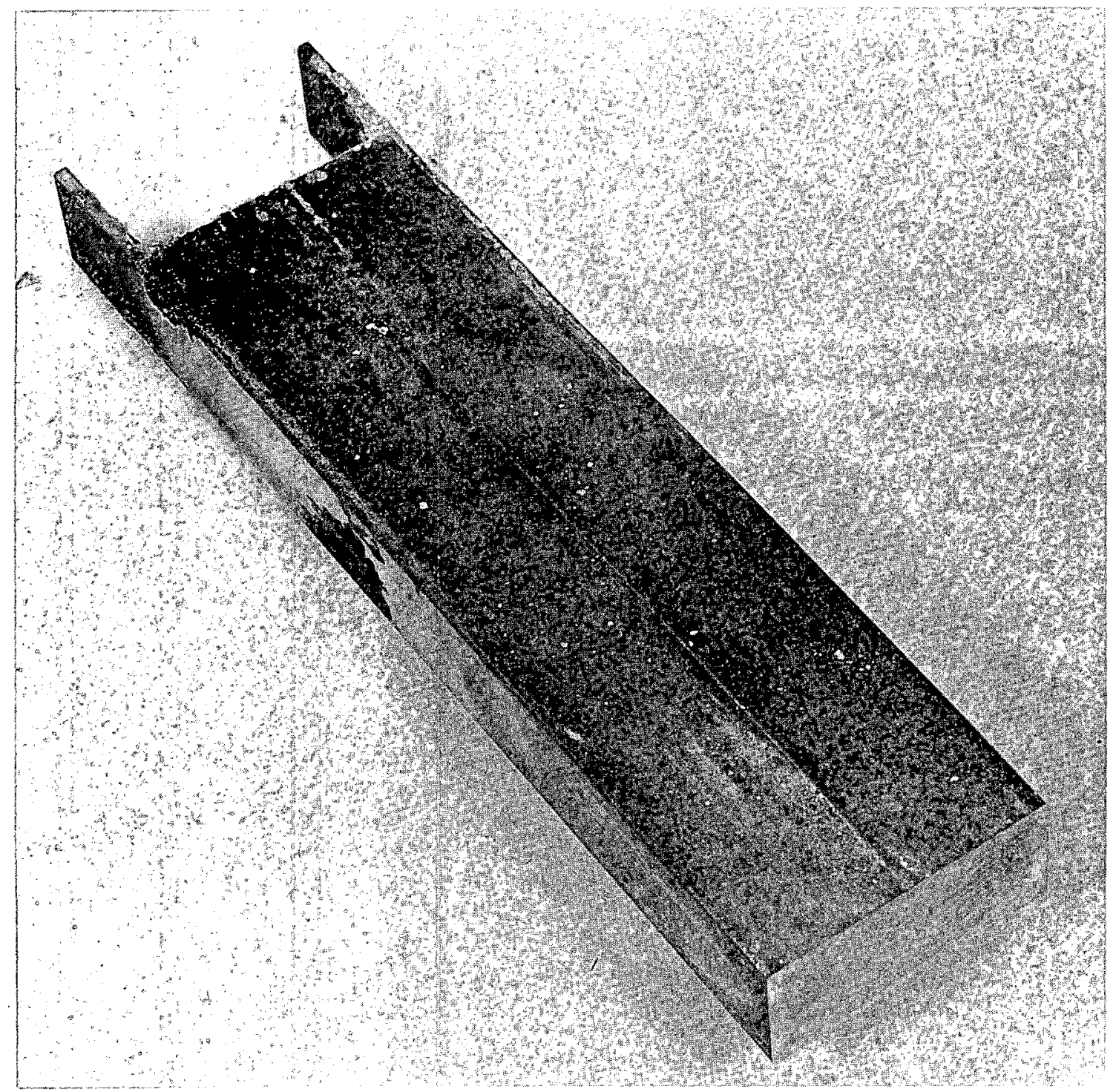

$106-1589$ 
FIGURE 24. Design and Dimensions of Zircaloy-2 Picture Frame for Bathtub Castings.

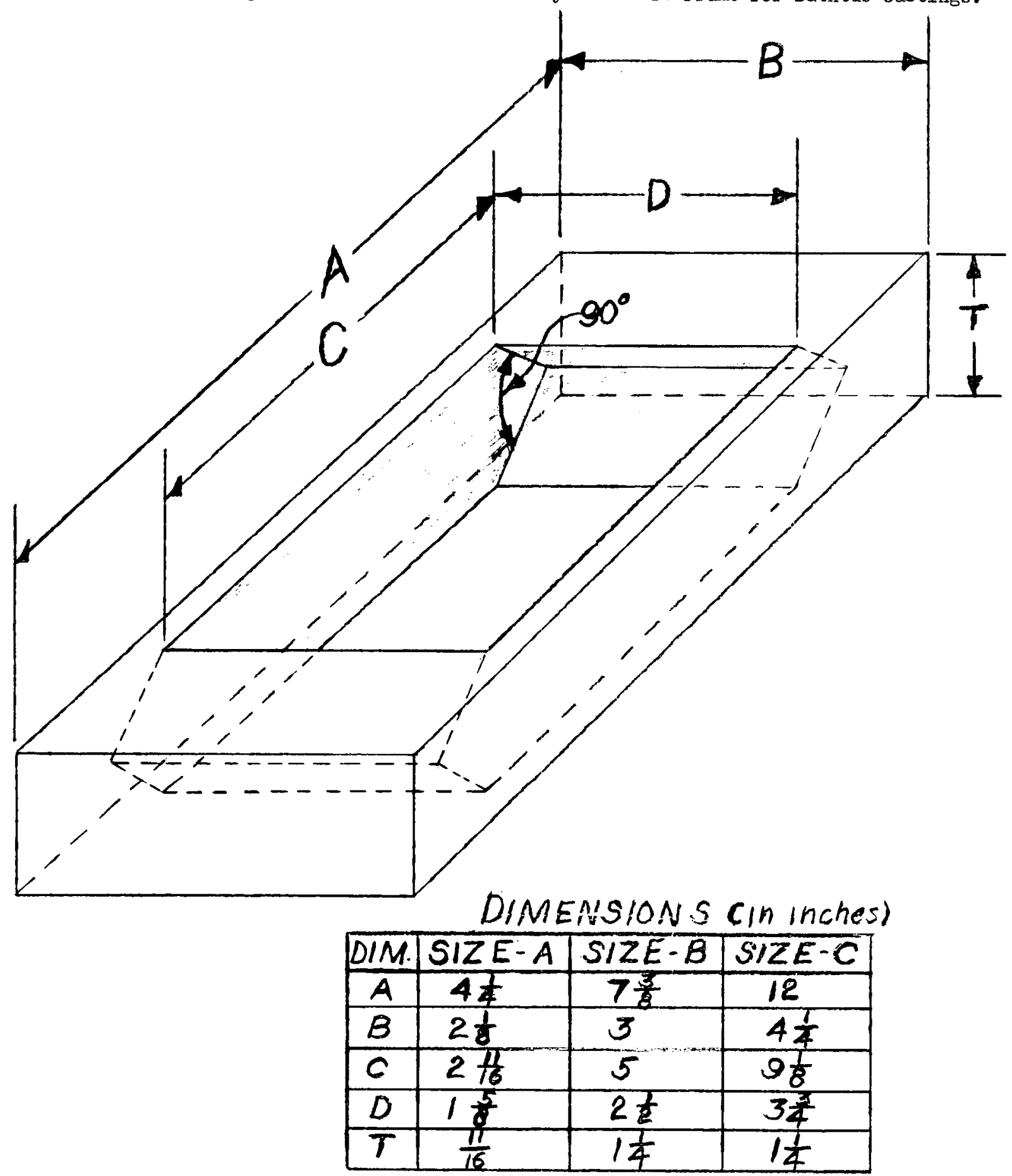


FIGURE 25. Sketch of Bathtub Mold for Casting Into Zircaloy-2 Frame.

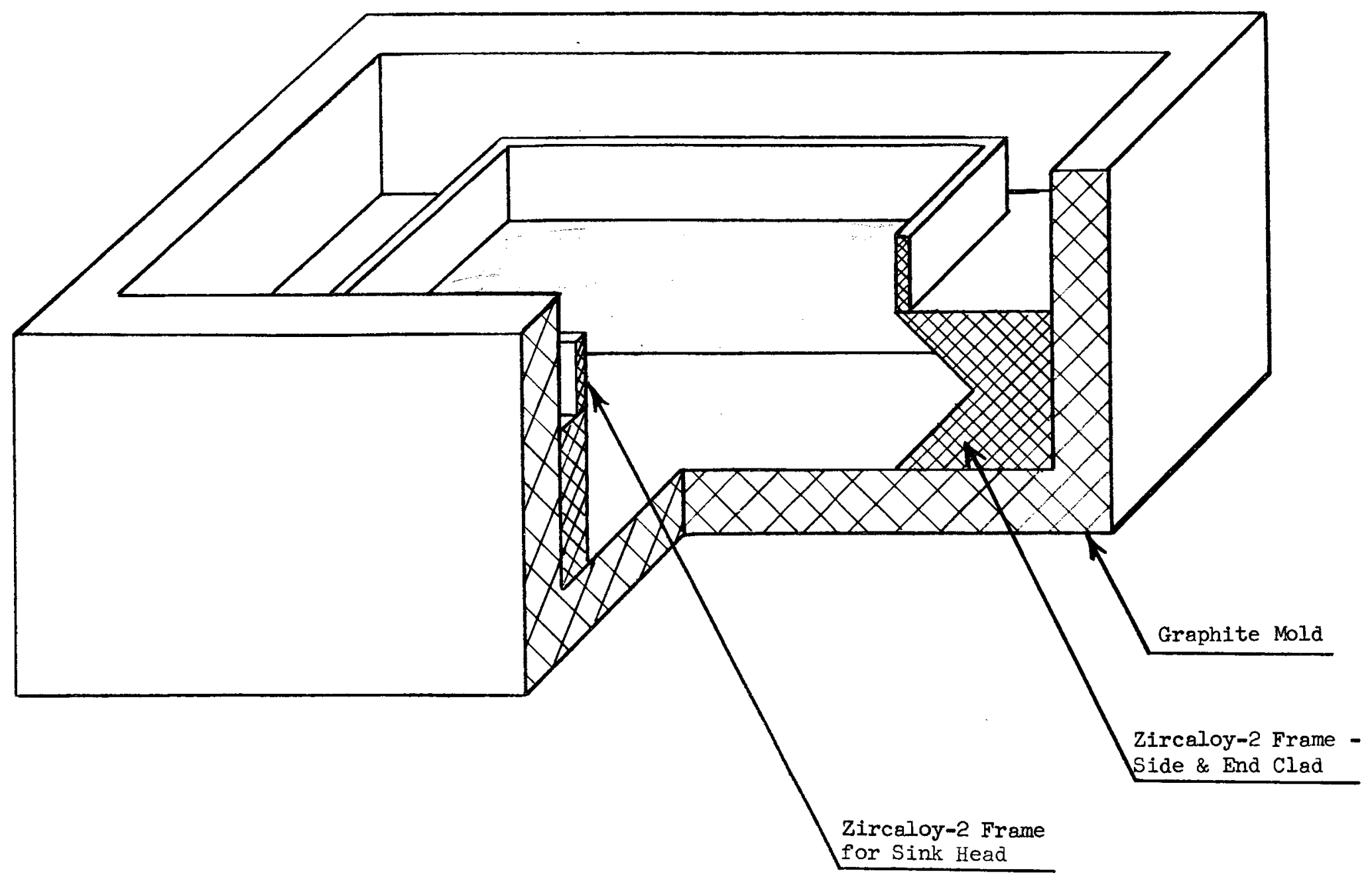


FIGURE 26. Bottom View of Two Bathtub Castings. Note Soundness in 1064 and Interfacial Porosity in 1068.

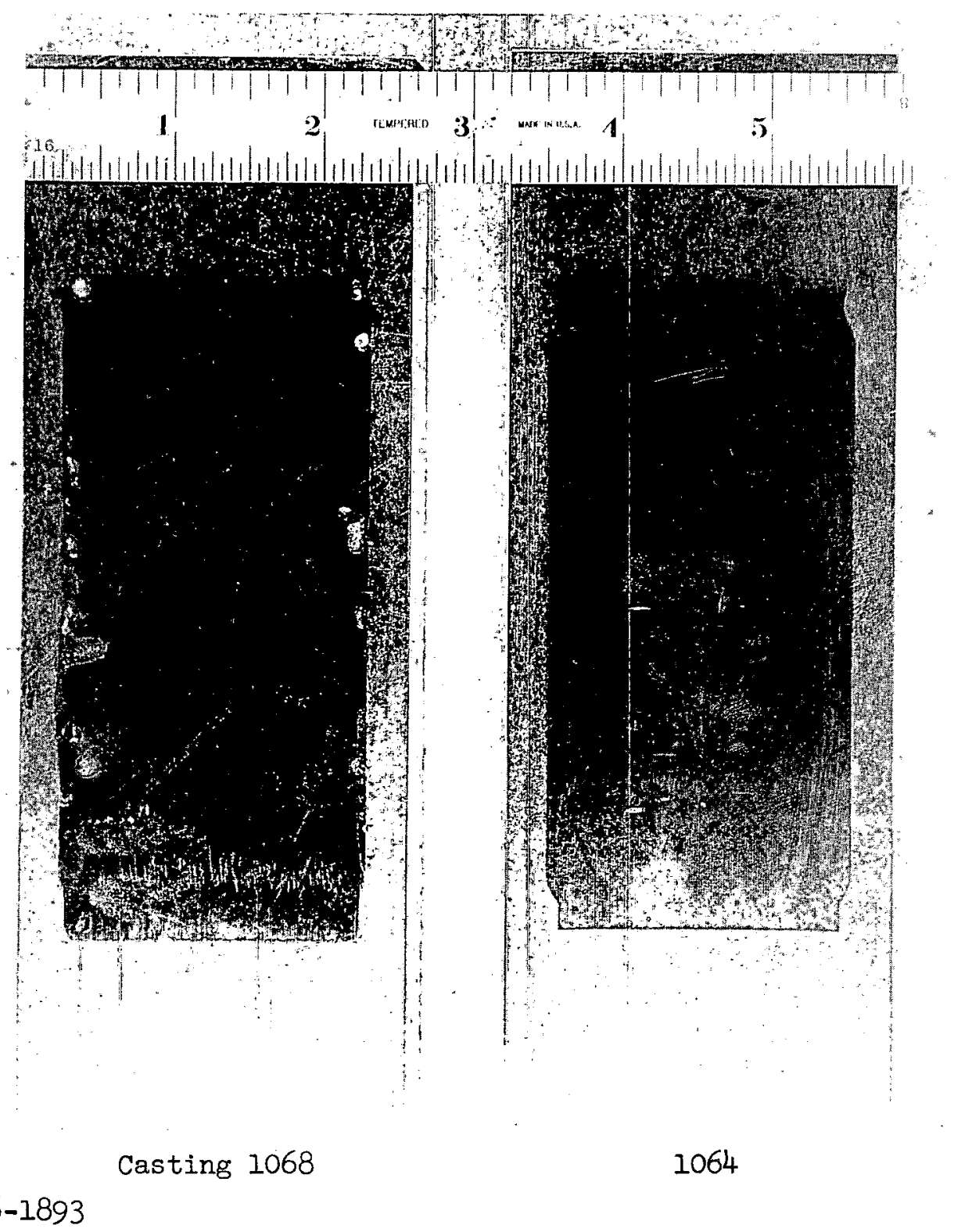

